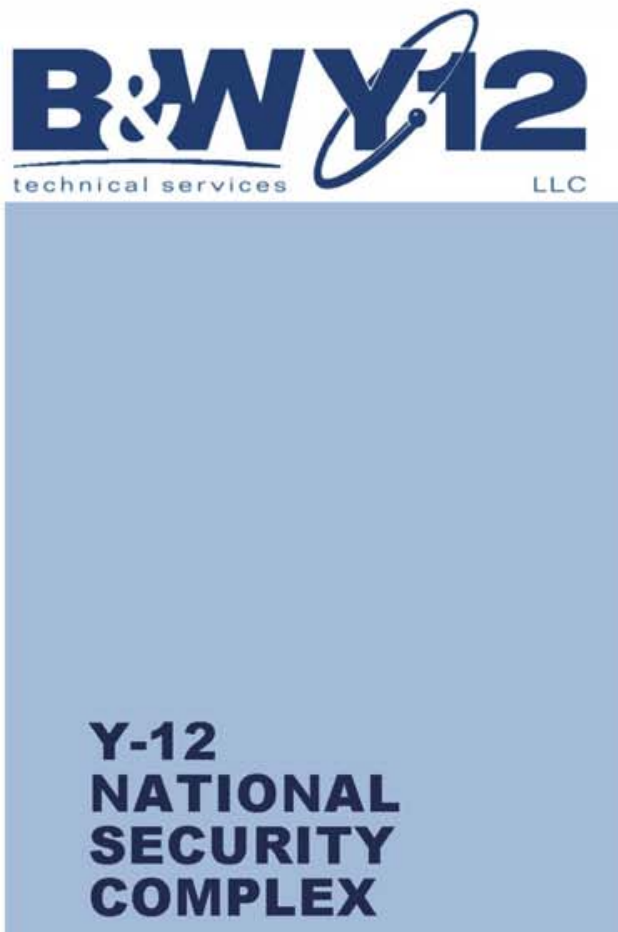

\title{
Y-12 Groundwater Protection Program Monitoring Well Inspection and Maintenance Plan
}

September 2013

Prepared by the

Environmental Compliance Department, Environment, Safety, and Health Division Y-12 National Security Complex Oak Ridge, Tennessee 37831

\author{
Managed by \\ Babcock \& Wilcox Technical Services Y-12, L.L.C. \\ For the U.S. DEPARTMENT OF ENERGY \\ Under contract DE-AC05-00OR22800
}




\section{DISCLAIMER}

This report was prepared as an account of work sponsored by an agency of the United States Government. Neither the United States Government nor any agency thereof, nor any of their employees, makes any warranty, express or implied, or assumes any legal liability or responsibility for the accuracy, completeness, or usefulness of any information, apparatus, product, or process disclosed, or represents that its use would not infringe privately owned rights. Reference herein to any specific commercial product, process, or service by trade name, trademark, manufacturer, or otherwise, does not necessarily constitute or imply its endorsement, recommendation, or favoring by the United States Government or any agency thereof. The views and opinions of authors expressed herein do not necessarily state or reflect those of the United States Government or any agency thereof. 


\section{Y-12 Groundwater Protection Program Monitoring Well Inspection and Maintenance Plan \\ Revision 4}

September 2013

Prepared by the

Environmental Compliance Department, Environment, Safety, and Health Division

Y-12 National Security Complex

Oak Ridge, Tennessee 37831

Managed by

Babcock \& Wilcox Technical Services Y-12, L.L.C.

For the U.S. Department of Energy

Under contract DE-AC05-00OR22800 
This page intentionally left blank 


\section{Table of Contents}

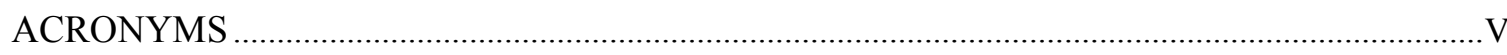

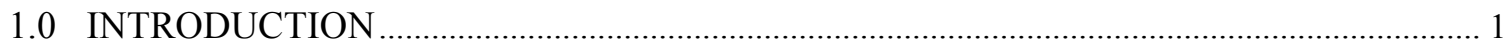

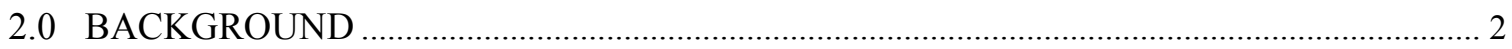

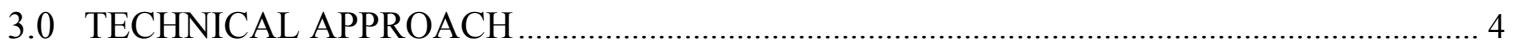

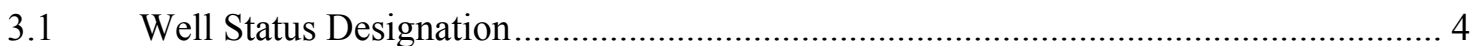

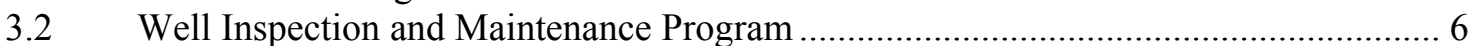

3.3 Well Inspection Items (Well Components) ...................................................... 8

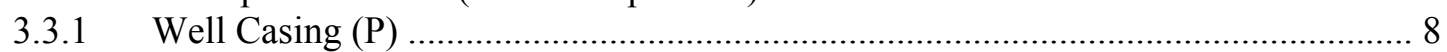

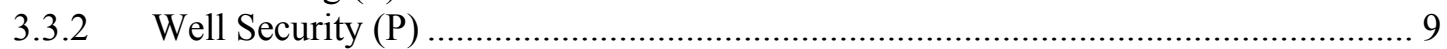

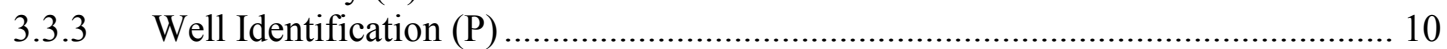

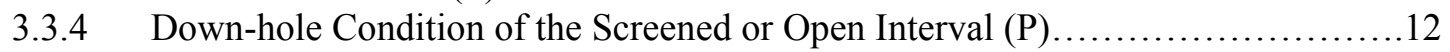

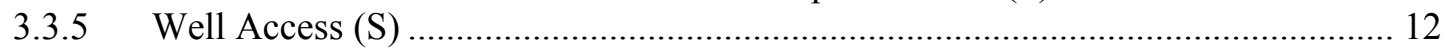

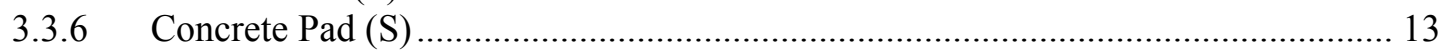

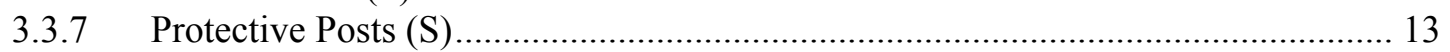

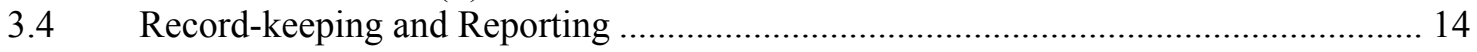

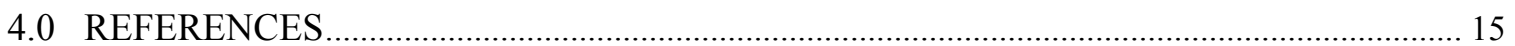

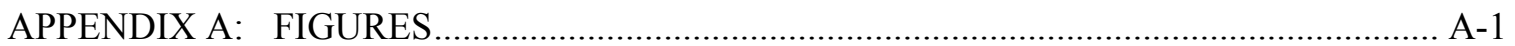

APPENDIX B: WELL COMPONENT SPECIFICATIONS ….....................................................

APPENDIX C： WELL INSPECTION CHECKLIST FORMS …............................................

APPENDIX D: WELL MAINTENANCE REQUEST FORM

PLUGGING AND ABANDONMENT REQUEST FORM .......................... D-1

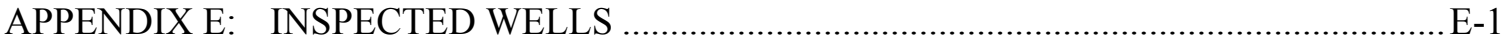


This page intentionally left blank 


\section{Acronyms}

$\begin{array}{ll}\text { AJHA } & \text { Automated Job Hazard Analysis } \\ \text { B\&W Y-12 } & \text { Babcock \& Wilcox Technical Services Y-12, L.L.C. } \\ \text { BCV } & \text { Bear Creek Valley } \\ \text { BJC } & \text { Bechtel Jacobs Company LLC } \\ \text { BWXT Y-12 } & \text { BWXT Y-12 L.L.C. } \\ \text { CERCLA } & \text { Comprehensive Environmental Response, Liability, and Compensation } \\ & \text { Act } \\ \text { CY } & \text { calendar year } \\ \text { DOE } & \text { U.S. Department of Energy } \\ \text { DOE-EM } & \text { U.S. Department of Energy - Environmental Management } \\ \text { FI\&S } & \text { Facilities, Infrastructure, and Services Organization } \\ \text { GIMS } & \text { Groundwater Information Management System } \\ \text { GWPP } & \text { Y-12 Groundwater Protection Program } \\ \text { JHA } & \text { Job Hazard Analysis } \\ \text { LCC } & \text { Low Clearance Cap } \\ \text { MOP } & \text { GWPP Monitoring Optimization Plan } \\ \text { MP } & \text { Measurement Point } \\ \text { P } & \text { Primary Inspection item } \\ \text { P\&A } & \text { plugging and abandonment } \\ \text { PVC } & \text { polyvinyl chloride } \\ \text { RCRA } & \text { Resource Conservation and Recovery Act } \\ \text { S } & \text { Secondary Inspection item } \\ \text { SS } & \text { stainless steel } \\ \text { TOC } & \text { top of well casing } \\ \text { TOWW } & \text { top of Well Wizard } \\ \text { UCOR } & \text { URS|CH2M Oak Ridge } \\ \text { VALA } & \text { Verification and Loading Application } \\ \text { WI\&M } & \text { Well Inspection and Maintenance } \\ \text { WMR } & \text { Well Maintenance Request } \\ \text { WW } & \text { Well Wizard }{ }^{\circledR} \text { Bladder pump - dedicated } \\ \text { Y-12 } & \text { Y-12 National Security Complex }\end{array}$

Note: In 2008, BWXT Y-12 underwent a name change to B\&W Y-12. 
This page intentionally left blank 


\subsection{INTRODUCTION}

This document is the fourth revision of the Monitoring Well Inspection and Maintenance Plan for groundwater monitoring wells installed at the U.S. Department of Energy (DOE) Y-12 National Security Complex (Y-12) in Oak Ridge, Tennessee (Appendix A, Fig. 1). This plan describes the systematic approach for:

- inspecting the physical condition of monitoring wells at Y-12,

- determining maintenance needs that extend the life of a well, and

- identifying those wells that no longer meet acceptable monitoring well design or well construction standards and require plugging and abandonment.

The inspection and maintenance of groundwater monitoring wells is one of the primary management strategies of the Y-12 Groundwater Protection Program (GWPP) Management Plan, "proactive stewardship of the extensive monitoring well network at Y-12" (Babcock \& Wilcox Technical Services Y-12, L.L.C. [B\&W Y-12], 2009b). Effective stewardship, and a program of routine inspections of the physical condition of each monitoring well, ensures that representative water-quality samples and hydrologic data are obtained from the well network and protects the subsurface environment. In accordance with the Y-12 GWPP Monitoring Optimization Plan (MOP) for Groundwater Monitoring Wells at the Y-12 National Security Complex, Oak Ridge, Tennessee (B\&W Y-12, 2009a), the status designation (active or inactive) for each well determines the scope and extent of well inspections and maintenance activities (see Section 3.0). This plan, in conjunction with the above document, formalizes the GWPP approach to focus available resources on monitoring wells which provide the most useful data.

This plan applies to groundwater monitoring wells installed at $\mathrm{Y}-12$ and the related waste management facilities located within the three hydrogeologic regimes (Appendix A, Fig. 2):

(1) the Bear Creek Hydrogeologic Regime (Bear Creek Regime),

(2) the Upper East Fork Poplar Creek Hydrogeologic Regime (East Fork Regime), and

(3) the Chestnut Ridge Hydrogeologic Regime (Chestnut Ridge Regime).

The Bear Creek Regime encompasses the section of Bear Creek Valley (BCV) immediately west of Y-12. The East Fork Regime encompasses most of the Y-12 process, operations, and support facilities in BCV east of Scarboro Road. The Chestnut Ridge Regime is directly south of Y-12 and encompasses a section of Chestnut Ridge that is bounded to the west by a surface drainage feature (Dunaway Branch, located immediately west of Industrial Landfill II) and by Scarboro Road to the east. The GWPP maintains an extensive database of geographic and construction details and related information for the monitoring wells in each hydrogeologic regime in the Updated Subsurface Database for Bear Creek Valley, Chestnut Ridge, and parts of Bethel Valley on the U.S. DOE Oak Ridge Reservation (BWXT Y-12 L.L.C. [BWXT], 2003a). A detailed description of the hydrogeologic framework at Y-12 can be found in the GWPP Management Plan (BWXT, 2009b). 


\subsection{BACKGROUND}

A regular program of well inspection and maintenance (WI\&M) was created by the GWPP after a 1989 DOE Tiger Team finding of non-compliance with U.S. Environmental Protection Agency guidance regarding well security and well access. After the initial finding, and upon further investigation, the following items were self-identified and documented for the existing well network at that time: well security, well access, well identification, and maintenance. A program of routine surveillances (i.e. well inspections) was initiated as a corrective action to the finding. These well inspections were intended as a means to survey and document (by means of paper checklists) the above items on an annual basis. Well Maintenance Requests (WMR) are generated from these surveillances and the maintenance work submitted to the Well Services Subcontractor or the Y-12 Facilities, Infrastructure, and Services (FI\&S) Organization for repairs. All maintenance work performed is inspected and documented and approved upon successful completion.

The WI\&M program was first outlined and formalized in Monitoring Well Inspection and Maintenance Plan for the Department of Energy Y-12 Plant, Oak Ridge, Tennessee (MMES, 1991). This plan:

- outlined a program for routine inspection of the physical condition of each monitoring well at $\mathrm{Y}-12$,

- identified well components to be inspected,

- defined minimum acceptable standards for each component,

- established a well maintenance program, and

- established procedures for performing and documenting well inspections and maintenance performed.

Procedures (G-001 and G-002) detailing the step-by-step process of well inspections and depth measurements, respectively, were first published with this plan. The 1991 plan required only that a Monitoring Well Inspection/Maintenance Summary be updated and reissued each year. The first revision of this plan (MMES, 1994) clarified the definition of active wells and updated the two procedures (G-001 and G-002). The second revision of this plan (LMES, 1996) created a new mechanism to track the status designation of a monitoring well. This second revision of the plan was prompted by the rapid growth of the monitoring well network during the mid-1990s and the changing regulatory requirements resulting in constant changes to the status designation of each well.

The third revision of the WI\&M Plan (BWXT, 2006b) incorporated the language and structure of the GWPP Monitoring Optimization Plan (MOP) to aide in determining the scope and extent of well inspections and maintenance activities (Section 3.1 and 3.2). That revision also removed the monitoring well construction summary, procedures G-001 and G-002, and the personnel training certification forms (see discussion in Section 3.2 for all of the above). Procedures G-001 and G002 were eventually combined and replaced by procedure Y71-66-EC-214 Monitoring Well Inspection and Depth Measurement (B\&W Y-12, 2012a). The current version of the MOP (B\&W Y-12, 2009b), is listed in the References section of this document. 
Beginning in 2009, well inspections were completed electronically. Specifically, the inspection checklists were completed using a laptop/tablet PC. This change was documented in Y71-66-EC214. The following are a list of the benefits of electronic media use for well inspections:

1. Reduces time to perform a well inspection in the field,

2. Reduces errors introduced through double entry,

3. Improves recordkeeping and reporting, and

4. Improves identification of maintenance requirements, prioritization, and planning.

A facsimile snapshot of the paper well inspection checklist is presented on the PC screen. The PC is pre-loaded with well construction information and the appropriate spaces on the form are automatically populated as each new location is identified. Rather than manually entering a chronological well inspection number (as was the procedure using the paper well inspection checklists), inspection numbers are now automatically assigned as the data is verified following an upload to the Verification and Loading Application (VALA) database.

The inspector goes through the checklist, answering questions based on his/her observation of the condition of the inspection items. If the response to a question identifies a maintenance need, the inspection application supplies the inspector with a comment box with a pre-loaded statement that is specific to the question just answered. The inspector can accept the response in the comment box, but also has the opportunity to elaborate on the specific details regarding the condition of the well or maintenance needs. In addition, when performing a triennial inspection, where a tag of the well total depth is required, the percentage of monitoring interval possibly blocked by sediment is automatically calculated by the inspection application once the measured depth has been entered into the appropriate space on the electronic checklist. The electronic well inspection checklist does not have the shaded boxes that are used on the paper well inspection checklists to identify maintenance needs. Instead, the maintenance needs of a particular monitoring well, or all of the wells exhibiting the same maintenance need can be compiled from the VALA database after inspection information has been uploaded and verified. With the electronic media, the inspection is complete only when all information has been entered, including the inspector's initials.

As of this publication, the GWPP Groundwater Information Management System (GIMS) includes a total of 1425 groundwater monitoring wells, boreholes, borings, and coreholes that have been installed or drilled at Y-12. These wells or borings were installed to meet various groundwater quality monitoring programs, research projects, remedial investigations, plume characterization and delineation studies, or other various hydrogeologic studies. Of those, 597 wells have been plugged and abandoned, have been destroyed, are not locatable, or are of unknown status. Of the 828 remaining wells, a total of 551 have been assigned a status designation of either active or inactive status in accordance with the current MOP (2013c) and will be the focus of the WI\&M program. For the remaining 277 wells or borings, the wells are: 1) not in service and will be scheduled for plugging and abandonment in the future or 2) are temporary piezometers or other specialized groundwater monitoring devices that were previously installed for research purposes, hydrologic testing, pilot studies, or short term investigations. 


\subsection{TECHNICAL APPROACH}

The technical approach of this plan involves:

- determining the status designation of the well (e.g., determines the inspection frequencyannual or triennial basis),

- establishing a program of routine well inspections to assess the physical condition of each well,

- identifying maintenance needs from the well inspections,

- prioritizing maintenance work based upon well status, well component, and available resources,

- documenting and verifying all maintenance work that is performed, and

- identifying wells that no longer meet GWPP technical specifications, or are damaged beyond repair, and must be decommissioned.

A step-by-step flow diagram (Appendix A, Fig. 3) illustrates the GWPP Well Inspection and Maintenance Program in detail.

The objectives of the plan are to:

- describe the well status designation,

- establish the current business practices of the GWPP Well Inspection and Maintenance Program,

- describe the role and duties of the Well Inspection and Maintenance Coordinator

- identify and describe the well components (inspection items),

- define the minimum acceptable standards for the condition of each well component,

- establish a maintenance program to correct or repair well components that do not meet these standards,

- describe how well inspection and maintenance activities are prioritized, managed, and documented, and

- describe the final publication of each inspection event and the maintenance activities performed during that time period (note: well inspection and maintenance activity reports are now compiled after each triennial inspection, and include the results/activities of the triennial inspection event, as well as the previous two annual inspection events).

\subsection{Well Status Designation}

The GWPP Monitoring Optimization Plan (MOP), first issued in 2003, formalized the technical approach the GWPP took to focus available resources on monitoring wells at Y-12 that provide the most useful hydrologic and water-quality monitoring data (BWXT, 2003c). The MOP formalized the definition of "active" and "inactive" status, outlined the process for determining a well's status designation, provided comprehensive lists of wells (approved by the GWPP Program Manager) that were granted either active or inactive status, and formalized how changes (additions, deletions, change in status designations) were documented (i.e. addenda).

The status designation (active or inactive) of a well determines the frequency of well inspection, the scope of the inspection, and the prioritization of maintenance. This WI\&M plan formally adopts the status designation of each well assigned in the MOP and focuses resources only on 
those well locations. This designation differs from past WI\&M plans where all existing wells, boreholes, coreholes, and borings were included in the WI\&M program.

The criteria for determining a well's status designation are briefly summarized below.

Active status is granted to:

- wells included in a regulatory program (Section 3.2),

- wells sampled specifically to address applicable groundwater monitoring requirements in DOE Orders 436.1 and 458.1,

- wells used to monitor groundwater surface elevations (referred to as hydrologic monitoring),

- wells known to yield contaminated groundwater, or

- wells located hydraulically down-gradient of a Y-12 facility, a known source of contamination, or that provide unique hydrologic or water-quality information (B\&W 2009b).

Changes to the status designation of a well are done with approval of the GWPP Program Manager and are documented in an addendum to the MOP. Active status will also be granted to any newly installed well that meets GWPP's design and construction standards, serves an ongoing regulatory program, and/or the programmatic needs of the GWPP. The status of the well may change if the well no longer meets any of the above criteria; the well has been damaged beyond repair, or at the discretion of the GWPP Program Manager (B\&W Y-12, 2009a).

Inactive status is granted to wells where:

- the well is not included in an active regulatory program,

- the well is not sampled specifically to address applicable groundwater monitoring requirements in DOE Orders 436.1 and 458.1,

- the design and construction details are unknown,

- the well components do not meet the technical standards of the GWPP or other requirements (e.g. all weather access),

- monitoring data are not available,

- the well is not located hydraulically down-gradient of any facility associated with Y-12 or any source of contamination, or

- the well monitors uncontaminated groundwater, or provides redundant monitoring coverage with other wells (B\&W Y-12, 2009a).

The status of a well may change from inactive to active if (1) one of the above conditions changes and/or (2) at the discretion of the GWPP Program Manager. A well is removed from the active or inactive list if the well is damaged beyond repair and an official plugging and abandonment (P\&A) request has been submitted.

There are two well inspection schedules for monitoring wells listed in the MOP: Annual and Triennial. Active wells are inspected annually ("Annual Inspection Checklist", Appendix C) for both primary (P) and secondary (S) inspection items (see discussion in Sections 3.2 and 3.3). Both the active and inactive wells are inspected on a triennial basis ("Triennial Inspection Checklist", Appendix C), and down-hole conditions are assessed at that time (by a well depth measurement). This differs from previous WI\&M plans where the down-hole conditions were evaluated every year. In 2003, a review of the depth measurements revealed that there was little, 
if any, substantial change in the measured depths at each well observed over multiple years, unless sedimentation was an obvious problem (Section 3.3.3). Maintenance on active wells is prioritized based on resources and need. Emphasis is placed on maintaining primary inspection items on all wells. Inactive wells are inspected for primary and secondary inspections items, but only primary inspection items are given priority (Section 3.2).

\subsection{Well Inspection and Maintenance Program}

For each calendar year (CY) inspection event, the WI\&M Coordinator compiles a list of wells from the MOP, includes/excludes wells added or removed from the MOP (addenda), and excludes all wells managed under "other programs" (active wells listed under "Regulatory Monitoring Programs" in the MOP). Currently, the Environmental Management Contractor to DOE (URS|CH2M Oak Ridge [UCOR]), has the responsibility for performing regulatory monitoring for the: 1) Resource Conservation and Recovery Act (RCRA) post-closure permits, 2) Comprehensive Environmental Response, Liability, and Compensation Act (CERCLA) Remedial Effectiveness and Records of Decision, 3) the four active Solid Waste Disposal Facility permits, and 4) the CERCLA Environmental Management and Waste Management Facility. In addition, UCOR has the responsibility for actively performing well maintenance on these wells.

The WI\&M Coordinator continues to compile the list of wells from the MOP and will:

1. remove any wells that have persistent, unsafe access problems, or are slated for plugging and abandonment, but have not been removed from the MOP,

2. compile well-specific information from the Subsurface Database (BWXT, 2003a) or past inspections for wells that have obstructions, dedicated pumps (that have to be pulled to get a depth measurement in wells with an inside diameter of 2.0 inches or less), off-normal wellhead configurations (pressure relief valves - no depth measurements), dedicated packers (no depth measurements), or flush-mount configurations,

3. communicate special instructions for known and/or posted well access requirements (off-road access, remote location, construction areas, active landfill operations, radiological work permits, bar-gated and fenced areas, contact number for entry, and keys needed for access) to field personnel performing the well inspections.

The WI\&M Coordinator groups the wells by geographic location and by controlled access to Y12 areas, and then provides field personnel with work packages assigned by group number. Each work package contains the list of wells to be inspected, the length of the screened or open interval of the well, the reference tag depth (see discussion in Section 3.3.4), special instructions (discussed above), and copies of well location maps from the most recent Subsurface Database (BWXT, 2003a). The program requirement is for all well inspections to be completed electronically, even if paper checklists are used in the field.

Field personnel are trained in accordance with B\&W procedure Y71-66-EC-214, Monitoring Well Inspection and Depth Measurement (B\&W Y-12, 2012a). This procedure combines and replaces GWPP procedures G-001 and G-002 for well inspection and depth measurements, respectively. Training is performed on an annual basis and qualifications are tracked and documented in Y-12 SAP business management database. The WI\&M Coordinator is responsible for assuring that all field personnel are qualified and have been briefed on the hazards and controls associated with the task to be performed. Field personnel are required to review and approve the applicable Job Hazard Analysis (JHA) prior to starting any work. 
Prior to performing well inspections, field personnel review work packages, all field information, and special instructions. Personnel gather appropriate equipment (weighted tape measures or taglines, bargate keys, plastic sheeting, plastic bags, and decontamination supplies), obtain a vehicle (4-wheel drive, if required), and make arrangements for access (posted conditions or contact numbers). When performing well inspections, field personnel verify the physical condition of each well location (note any newly posted or access requirements), complete primary and secondary inspection items on the checklist (see Section 3.3), perform and record a depth measurement (if required), note whether dedicated monitoring equipment is present, note if the depth measurement was soft or hard, and note any other problems or anomalies. If the well inspection checklists are recorded on paper, the personnel performing the paper inspections are responsible for transferring this information to the appropriate electronic checklist, and then uploading to VALA. Electronically, the information is uploaded directly to the VALA database. The WI\&M Coordinator, or designee, is then required to verify each checklist before it becomes a final record in the database. Field personnel report any abnormalities observed in the field and any items that require immediate attention to the WI\&M Coordinator.

The WI\&M Coordinator queries the VALA database for individual inspection items that require maintenance. Maintenance items are prioritized according to well status, primary $(\mathrm{P})$ or secondary (S) inspection items, and available resources. A Well Maintenance Request ([WMR], see Appendix D) is initiated indicating the type of maintenance requested (P or S) and a detailed description of the maintenance work needed. The WMR is the official record of GWPP maintenance activities, documenting the work requested, actual work performed, and noted exceptions. Each WMR is assigned a unique identifier (the first two digits designate the CY, followed by a unique three digit number (typically assigned chronologically), and a $\mathrm{P}$ or an $\mathrm{S}$ (depending on whether the maintenance need is to a primary or secondary inspection item). The WMR is issued to a service provider (Well Service Subcontractor or the Y-12 FI\&S Organization) to perform the maintenance work. The service provider may perform a walk-down of the requested work, provide input, and a cost estimate based on the scope of work. The maintenance work is performed by the service provider in accordance with the scope of the technical specifications outlined in the WMR, this plan (see Section 3.3), and/or a specified statement of work. All maintenance work is inspected for completeness and any problems, comments, or deviations from the agreed upon scope of work is documented (where work cannot be completed as requested) on the WMR.

If the condition of a primary inspection item is beyond practical remediation or if the well is damaged beyond repair, the WI\&M Coordinator initiates a plugging and abandonment (P\&A) request (Appendix D) and submits it to the GWPP Program Manager for approval. The P\&A request documents: 1) the reason for P\&A (including comments/explanation for the P\&A), 2) the individual whom submits the $P \& A$ request (including the date the request was submitted), 3) licensed driller who performs the P\&A (including the date P\&A was completed), and 4) all P\&A documentation of the event (daily log sheets, diagrams, etc.). Each $P \& A$ request is given a unique identifier: the first two digits designate the calendar year, followed by a unique three-digit number (typically assigned chronologically)). The well is removed from the active or inactive well list in the MOP once P\&A has been performed and approved. The status of the well in GIMS is changed to "P\&A", and the date of the P\&A is entered. Well inspection checklists, along with completed WMRs and $\mathrm{P} \& \mathrm{~A}$ requests, are published in a triennial Well Inspection and Maintenance Report, as specified in Section 3.4. 


\subsection{Well Inspection Items (Well Components)}

Active and inactive wells under the GWPP Well Inspection and Maintenance Program are inspected for both primary and secondary inspection items (Note: generalized schematic diagrams of monitoring well components are found in Appendix B), each relating to a specific well component. Primary $(\mathrm{P})$ inspection items are those well components that ensure representative subsurface conditions for sampling and hydrologic monitoring purposes. These components include the condition of the well casing, well security, well identification, and the down-hole condition of the screened or open interval. Because the primary inspection items are crucial to the well's integrity and its ability to provide representative data, these inspection items are given a higher priority for maintenance. Secondary (S) inspection items are those components of a monitoring well that if damaged or compromised will not generally affect the collection of representative groundwater analytical samples or hydrologic information. These items include well access, concrete pad, and protective posts. For active wells, secondary inspection items will be maintained, but for inactive wells (unless there is a safety concern) maintenance of secondary items are performed on an as-needed basis.

\subsubsection{Well Casing (P)}

Well casing diameter, material type, and construction have varied dramatically over the last 25 years of well installations at Y-12. Well casing type was often dependent upon the project/program requirements, the drilling subcontractor, the well's depth, and the original purpose of the installation (hydrogeologic study, corehole, piezometer, water table well, bedrock well, or regulatory compliance well). In general, two types of monitoring wells are installed at Y12: wells completed with screened intervals and wells completed with open-hole monitoring intervals (open borehole below the cased section of the well).

Screened wells typically are used for monitoring groundwater in both unconsolidated and bedrock zones. Open-hole monitoring wells are used primarily for monitoring groundwater conditions in the competent bedrock interval. Most wells have a surface casing to hold the borehole open in the unconsolidated and weathered bedrock zones during construction and prevent crosscontamination between the various aquifers, then a smaller diameter riser casing is installed to the monitoring interval. Other types of holes that exist at Y-12 have been constructed for the purpose of subsurface investigations, or sampling, include: coreholes, boreholes, drivepoint wells, piezometers/temporary wells (typically 1 -in. or less in diameter), and open borehole wells instrumented/installed with dedicated sampling devices (Section 3.3.2). The well-head configurations on these holes are similar to those described below.

For monitoring wells that have a screened interval, the well (riser) casing and screen are typically constructed of either stainless steel (SS) or polyvinyl chloride (PVC) material. Wells constructed of PVC require an outer protective casing (although not usually present for older generation PVC wells or small diameter drivepoints/piezometers), which encases the inner riser casing stick-up (casing that extends above the ground surface). This can be an extension of surface casing (mentioned earlier) extending above ground surface, or an outer protective casing installed after the installation of the well (Appendix B, Fig. 4). The outer protective surface casing provides additional protection against vehicular damage (e.g. PVC riser casing is easily damaged), provides well security, and protects the PVC casing from degradation from direct sunlight. Wells constructed of SS normally do not require an outer protective surface casing (Appendix B, Fig. 5), but it was sometimes installed for 2-inch SS wells, to provide additional protection. 
Bedrock wells with open-hole intervals are constructed with steel well casing which is often extended above the ground surface, and serves as protective casing (Appendix B, Fig. 7).

Riser casings and outer protective surface casings are inspected for signs of physical deterioration or damage, such as cracks, corrosion, breaks, dents, and bends that can affect the structural integrity of the well. Any well casing that has sustained damage should be noted on the well inspection checklist. Also, any exposed portion of the annular grout seal (see Appendix B, Figs. 4 and 5; not normally seen on most wells) should be inspected for signs of deterioration (e.g., loose casing) or for cracks and breaks due to degradation or from wells that have experienced damage. For wells where it is possible for water to collect between the outer protective surface casing and the well casing itself, a weep-hole must be installed in the outer protective casing to allow the water to drain and prevent freezing damage to the well casing (stick-up).

Wells with a flush-mount design are typically employed in high traffic areas of Y-12 (Appendix B, Fig. 6). The riser casing is cut off below the ground surface, and the uppermost portion of the well casing is housed below grade inside a christy box, manhole enclosure, or vault, with a traffic cover that bolts securely to the flush-mount box. In addition to standard inspection items, flushmounted wells will be inspected for the following:

1) the presence of an intact concrete apron (pad) around the manhole enclosure and whether the enclosure is installed slightly elevated above grade with the concrete apron sloping away from the well;

2) the presence of a gasket seal for the traffic cover, and its condition (does not allow water to enter the manhole enclosure);

3) whether the traffic cover is securely bolted to the manhole enclosure;

4) whether water collects inside the manhole enclosure; and

5) the presence of a water-tight locking cap (sometimes called a "pipe plug"), the condition of the cap, and whether it makes a water-tight seal with the casing.

Casing maintenance may involve replacing or extending the outer protective casing (or riser casing) portion that is above ground; adding outer protective casing around the riser casing; replacing/repairing the christy box/manhole enclosure/vault for flush-mounted wells; adding grout in the annular space between the well casing and the outer protective casing; and repairing the annular grout near the ground surface (if the casing is loose).

\subsubsection{Well Security (P)}

To prevent unauthorized access, all monitoring wells at Y-12 are secured with stainless steel or brass locks. The type of well cap and locking configuration is based on the type and diameter of the riser casing, or the outer protective casing, and whether a dedicated bladder pump (Well Wizard $^{\circledR}$ ) or monitoring system (Westbay ${ }^{\circledR}$ Instrumentation or BarCad ${ }^{\circledR}$ unit) is installed in the well. Wells with stainless steel casings normally have a stainless steel slip-on well cap that locks through aligned hasps welded to the cap and to the outside of the well casing (Appendix B, Fig. 8). PVC wells, with no outer protective casing, usually have a locking water-tight well cap (sometimes called "pipe plug") with a slip-on PVC cap. For PVC casing with an outer protective casing (6-in.), an aluminum casing lid (some have a square stainless steel casing with welded hasp) slips on over a hasp or a post welded to the outside of the protective casing (Appendix B, Fig. 8). For steel casing wells (open-interval bedrock wells that are: 4-in., 7-in., or 10-in. in diameter), an aluminum slip-on Royers ${ }^{\mathrm{TM}}$-type collar bolts to the top of the casing and the manufactured lid slips over the collar (Appendix B, Fig. 8). There is a machined hole in the lid 
and a corresponding hole on the collar to lock the lid. This design is typical of all wells with steel protective casing (usually 7-in. or 10-in. in diameter). For flush mounted wells (Appendix B, Fig. 7), a lockable water tight cap is required, independent of casing type or diameter.

Wells installed with dedicated Well Wizard ${ }^{\circledR}$ (WW) sample pumps have a different well cap and locking configuration (Appendix B, Figs. 9 and 10) than those listed above. The WW cap contains the connection fittings to operate the bladder pump; suspended by tubing below the cap. The different WW cap styles depend on the casing type, diameter, and the year the pumps were purchased and deployed. Most wells with dedicated WW pumps have a white PVC WW cap (Appendix B, Fig. 9): the base of which is actually a casing extension piece that slips-on over the well casing or the outer protective casing. A plate that holds the tubing fittings, from which the pump is suspended, rests on a ledge inside the casing extension piece. A top cap is secured to the casing extension piece with a locking pin that slips through the extension piece, locking the cap in place. Wells with dedicated WW pumps purchased in recent years have a low clearance cap (LCC), which rests on top of the well casing with the pump and tubing suspended below. These LCCs fit underneath the existing well caps (described above) which use the existing well cap, hasps, and lock (Appendix B, Fig. 10).

The addition of these white PVC WW caps raise the reference measurement point from the top of the well casing (TOC) to the top of the WW (TOWW) cap (Section 3.3.3.). This change in measurement point (MP) must be noted when making a total depth measurement to assess downhole conditions of the well. In most cases, the difference in height of going from a TOC MP to a TOWW MP has already been determined for the majority of the wells at Y-12.

Locks are inspected for corrosion and operation of the locking mechanism. All wells should have an assigned Y-series lock, each with a unique number (i.e., Y0668). Hasps are visually inspected for corrosion, damage, and the overall condition of the welds. Hasps or hinges found to be substantially corroded will be replaced. Locks that are corroded or difficult to operate will be replaced; no lubricants will be used to improve performance of the lock mechanism because these substances may detrimentally impact water quality samples collected from the well. If a well shows evidence of tampering (i.e. bolt-cut locks or broken hasps), the inspection personnel will notify the WI\&M Coordinator for further action. Well caps are inspected for snugness to the casing, and should not be removable without removing the lock first. Inspect all WW caps and extension pieces for damage, cracks, or looseness. Wells with missing caps and locks should be reported to the WI\&M Coordinator immediately.

\subsubsection{Well Identification (P)}

Correct well identification is crucial for tracking all subsequent sampling and monitoring data obtained from the well. All monitoring wells must be accurately identified. All monitoring wells are required to have a well tag - a stainless steel or aluminum plate (Appendix B, Fig. 11) engraved, stamped, or etched with the well identification number. The well identification tag is attached to the riser casing, or to the outer protective casing, using a stainless steel cable (1/16-in. in diameter) or an aluminum ring threaded through a stainless steel pipe band that tightens to the casing. The well identification tag should be inspected to ensure that the well number is legible and correct. Tags with illegible or incorrect well numbers will be replaced. Field personnel must verify that the well identification tag corresponds to maps provided in the latest revision of the Subsurface Database (e. g. BWXT, 2003a). Additional well identification may also be present that includes: the well number engraved on the well cap, well number written on the well cap or casing, or the well number stenciled (painted) on the casing (Appendix B, Fig. 12). Stenciling is 
the recommended secondary identification method, but the well identification tag is required for all wells.

\subsubsection{Down-hole Condition of the Screened or Open Interval (P)}

The down-hole condition of the screened or open interval can only be evaluated directly through the use of a down-hole video camera or the analysis of well performance information (e.g. hydraulic conductivity, pumping rates, specific yield, pumping duration), which is beyond the scope of this plan. For example, well screen deterioration caused by chemical or biological incrustation can result in substantial reduction in well yield (Driscoll, 1986). Depth measurement is the standard direct method of measuring any change in the down-hole physical condition of a well. By comparing these measurements to a reference depth (see discussion below) it can be determined if changes are occurring in the condition of the monitoring interval due to differences in the measured and reference depths. Significant differences $(>20 \%$ of the screened or open interval) between the measured depth and the reference depth may indicate:

- field measurement errors (e.g., wrong well, recording errors, or incorrect measurement reference point used); errors in the weighted tape used to measure the depth (e.g., stretching, can't read tape increment); or MP changes due to casing length changes (e.g., construction)

- accumulation of sediment or other debris (encrustation by-products) in the bottom of the well, or

- obstructions in the well which would provide an inaccurate depth measurement, and could possibly be caused by: 1) structural failure of the well casing or screen, 2) cave-in of the borehole wall within the open interval of the well, 3) instrumentation stuck in the well, or 4) snagging of measurement device due to down-hole orientation of casing or screen joints and the degree of vertical deviation of the well.

Many wells at Y-12 exhibit accumulations of sediment, which may eventually fill/plug the screened or open interval if it is not removed by re-development. This sediment can affect the performance of the well and the quality of analytical samples obtained from the well. The accumulation of sediment in the bottom of a well accounts for the differences between the reference depth (see discussion below) and the measured depth. Depth measurements are taken in accordance with Y-12 procedure Y71-66-EC-214, Monitoring Well Inspection and Depth Measurement (B\&W Y-12, 2012a).

All depth measurements are taken from a reference mark (designated official reference/correct Measurement Point) located either at the top of the innermost casing (riser casing, not the outer protective casing) recorded as feet below TOC, or from the top of the white PVC Well Wizard (WW) extension piece, recorded as feet below top of Well Wizard (TOWW). These are recorded to the nearest hundredth of a foot. The WW extension piece can extend the height of the riser casing (from $0.2 \mathrm{ft}$. to $1.0 \mathrm{ft}$, or more depending on cap design, see Appendix B; Fig. 9). The height of the sediment accumulation in the well is calculated by subtracting the measured depth (made from the official measurement point at the top of the casing or WW) from the reference depth ("well reference depth" on the checklist and dividing by the length of the screened or open interval). When completing the well inspection checklist electronically, the well inspection program in the inspection checklist application automatically calculates the percentage of the screen/open interval that is blocked by sediment. If the result of the calculation is 0.2 or greater, the interval is considered to be $\geq 20 \%$ filled, and a WMR is initiated requesting the well be rehabilitated (re-developed) and the sediment removed. 
In previous WI\&M plans, the constructed depth was used as the reference depth ("well depth" on the checklist, see Appendix C). The constructed depth is a calculated value based on well construction details provided in the Subsurface Database (BWXT 2003a). Because there have been unexplained differences between the original well construction data and what is observed in the field, problems arose when using these constructed depth values in the calculation to determine the amount of sediment accumulation in a well. Discrepancies included: the measured depth being several feet deeper, or shallower, than the constructed depth over several measurements, but no other indication of sediment accumulation, obstruction and/or equipment in the well, or any other structural failure in the well.

These discrepancies were first noted in the 1991 Well Inspection and Maintenance Plan (MMES 1991 ) and in all subsequent published annual well inspection and maintenance reports (see examples: BWXT 2002, BWXT 2003b, BWXT 2004, BWXT 2006a, B\&W Y-12 2008 [CY 2006 report], and B\&W Y-12 2013 [CY 2009 report]). A number of inspections revealed that these discrepancies were substantial, and remained consistent over several inspection events. Starting with the CY 2003 well inspection event, an agreed upon reference depth (referred to as "reference tag depth"), based upon several past depth measurements (obtained in CY 1994, CY 1997, and CY 2000), was used in lieu of the constructed depth (BWXT, 2002). These reference tag depths (see Appendix E) will be utilized in all future well inspections and updated as necessary. As of this publication, Appendix E includes the reference tag depth for all of wells that are inspected by the GWPP. Wells inspected by the GWPP include wells granted active or inactive status in the MOP (B\&W Y-12, 2009a), wells from which the GWPP obtains annual water level data, and wells that are sampled by the GWPP.

The WI\&M Coordinator provides additional well specific information to field personnel (Section 3.2) for wells that have obstructions or dedicated pumps in the well. For all 2-inch wells, dedicated sampling equipment will need to be removed prior to performing a depth measurement. During pump removal, groundwater from the sampling equipment will need to be contained as directed in the GWPP Waste Management Plan (found in the most recent edition of the GWPP Sampling and Analysis Plan. Field personnel are required to note any other abnormalities, different than the information provided, or note any other reason that the measured depth differs significantly from the well depth. Field personnel are also required to indicate whether a depth measurement was hard or soft (an indicator of possible sediment buildup at the bottom of the well), and the presence of, if possible, the amount of any mud observed on the weighted tape when it has been removed from the well.

Where the measured and reference tag depths differ substantially, the WI\&M Coordinator must determine if:

- a field measurement error occurred,

- the measurement did not pass an obstruction or dedicated instrumentation,

- a new obstruction has occurred,

- sedimentation has occurred, or

- a structural failure has occurred.

\subsubsection{Well Access (S)}

Groundwater monitoring wells must be accessible in all weather conditions. Well access road conditions range from paved (asphalt and/or concrete) to gravel to dirt/grass. Most well sites 
inside the fenced section of Y-12 are paved and easily accessible. Well access roads comprised of gravel, dirt, or grass, are common outside the fenced area of Y-12 and may or may not be maintained for use by another organization (security, power operations, landfill operations, etc.). These roads are more susceptible to damage with heavy use, heavy equipment (mowers), and continual exposure and erosion over time (washouts, ruts, gullies, and potholes). These roads require continual maintenance, ranging from mowing (roads become quickly overgrown presenting visibility limitations for the driver) to re-gravelling and re-grading.

Well access for all road types should be inspected to identify conditions that require maintenance (overgrown conditions, gullies, erosion of the road surface, or culvert damage) or preclude access to the wells (e.g., construction activities, impassible roads, newly posted conditions, or fallen trees). Access restrictions and requirements not already provided by WI\&M Coordinator (Section 3.2) should be noted on the inspection checklist. Any new conditions or restrictions should be noted and communicated to the WI\&M Coordinator. Maintenance involves mowing, bush hogging, weed-eating, and removal of obstacles blocking the access road (e.g., construction fencing, fallen trees, equipment, storage material, jersey barriers, and temporary buildings).

Repairing and re-grading road surfaces will be done on an as-needed basis and dependent upon well status and available resources. Maintenance may also involve removing barriers that block access to wells.

\subsubsection{Concrete Pad (S)}

Concrete pads are used to prevent infiltration of surface water (and subsequently surface contamination) through the annular space between the borehole and the casing. A surface pad (3 $\times 3 \times 0.75 \mathrm{ft}$., minimum) of concrete is emplaced (Appendix B, Fig. 13) around the outermost casing. Concrete pads are present for most active monitoring wells, but wells installed prior to 1986 may or may not have a pad. The installation or repair of concrete pads at the wells will be evaluated on a case-by-case basis.

The top of the concrete pad should be a minimum of 3-in. above ground level and sloped away from the well to prevent water from ponding around the well casing or protective surface casing. Inspection of the concrete pad will include identifying any damage (cracks, breaks, deterioration), and determining whether the top of the concrete pad is properly sloped. Maintenance may include patching cracks, patching damaged or deteriorated areas of the pad, replacing the pad, stabilizing the existing pad, or placing additional concrete to ensure that the pad is properly sloped.

\subsubsection{Protective Posts (S)}

Protective posts, guard posts, or bollards are required for all active monitoring wells, to protect the exposed riser casing stick-up (portion above ground surface) from collision damage (e.g., mowing equipment, vehicular traffic, heavy equipment). Up to four posts are typically installed around each monitoring well, with a minimum of $3 \mathrm{ft}$. of the post below the ground surface (Appendix B, Fig. 14). Posts are generally located at the corners of the concrete pad, and painted high-traffic yellow (for visibility), or provided with an appropriately colored durable plastic sleeve. Placement of the posts should protect the well from all potential traffic approaches (normally $4 \mathrm{ft}$. to $5 \mathrm{ft}$. apart). The height of the posts (a minimum of $3 \mathrm{ft}$. above ground surface) should protect the well from collision damage and allow work-over rigs and sampling vehicles access to the well. The posts should be inspected for physical damage or deterioration, paint degradation, and proper positioning. Maintenance will generally involve repainting or the 
installation of plastic bollard sleeves, but damaged posts must be replaced and additional posts may be installed if conditions warrant.

\subsection{Record-keeping and Reporting}

The records generated by the Well Inspection and Maintenance Program include:

- well inspection checklists (annual and triennial),

- well maintenance requests (generated as needed),

- plugging and abandonment requests (generated as needed), and

- Monitoring Well and Inspection Reports, most notably the CY 2006 Triennial Report (B\&W Y-12, 2008), the CY 2009 Triennial Report (B\&W Y-12, 2013a), and the CY 2012 Triennial Report (B\&W Y-12, 2013b).

These records have been published in annual Well Inspection and Maintenance reports (BWXT, $2002,2003 \mathrm{~b}, 2004 \mathrm{~b}$, and 2006a) for the year in which they were generated. Beginning in CY2009, inspection records have been recorded electronically and uploaded directly into the VALA database. Following the CY 2003 well inspection event, publishing of the WI\&M Report has been on a triennial basis and includes: a well inspection/maintenance summary for each year's inspections, the checklists from the triennial well inspection event, and all well maintenance requests and P\&A requests that were issued and completed since the last WI\&M report.

A record copy of this WI\&M plan is kept on file by the GWPP and Y-12 Central Records. This plan will be reviewed on a triennial basis for obsolescence, and updated as needed to reflect current business practices of the WI\&M program. The status designation of wells (active and inactive), as specified in the MOP, is not static and any changes to this status will be documented in addenda to the MOP.

Training records of field personnel to procedure Y71-66-EC-214, Monitoring Well Inspection and Depth Measurement, are maintained in Y-12 SAP business management database. 


\subsection{REFERENCES}

Babcock \& Wilcox Technical Services Y-12, L.L.C. (B\&W Y-12). 2008. Y-12 Groundwater Protection Program CY 2006 Triennial Report of the Monitoring Well Inspection and Maintenance Program, Y-12 National Security Complex, Oak Ridge, Tennessee.

Prepared by the Environment, Safety, and Health Division (Y/TS-2117).

B\&W Y-12. 2009b. Groundwater Protection Program Management Plan for the U.S. Department of Energy Y-12 National Security Complex, Oak Ridge, Tennessee. Prepared by Elvado Environmental L.L.C. (YSUB/01-006512/2/R2).

B\&W Y-12. 2012a. Monitoring Well Inspection and Depth Measurement. B\&W Y-12 Procedure, prepared by the Y-12 Environment, Safety, and Health Division (Y71-66-EC-214).

B\&W Y-12. 2012b. Y-12 Groundwater Protection Program Groundwater and Surface Water Sampling and Analysis Plan for Calendar Year 2013. Prepared by Elvado Environmental L.L.C., (Y/SUB/12-073231/2).

B\&W Y-12. 2013a. Y-12 Groundwater Protection Program CY 2009 Triennial Report of the Monitoring Well Inspection and Maintenance Program, Y-12 National Security Complex, Oak Ridge, Tennessee Prepared by the Environment, Safety, and Health Division (Y/TS2349).

B\&W Y-12. 2013b. Y-12 Groundwater Protection Program CY 2012 Triennial Report of the Monitoring Well Inspection and Maintenance Program, Y-12 National Security Complex, Oak Ridge, Tennessee Prepared by the Environment, Safety, and Health Division (Y/TS2352).

B\&W Y-12. 2013c. Y-12 Groundwater Protection Program Monitoring Optimization Plan for Groundwater Monitoring Wells at the U. S. Department of Energy, Y-12 National Security Complex, Oak Ridge, Tennessee. Prepared by Elvado Environmental L.L.C. (Y/TS-2031/R2).

BWXT Y-12, L.L.C. (BWXT). 2002. Results of Calendar Year 2000 Monitoring Well Inspection and Maintenance Program, Y-12 National Security Complex, Oak Ridge, Tennessee. Prepared by the Y-12 Environment, Safety, and Health Division (Y/TS-1872).

BWXT. 2003a. Updated Subsurface Data Base for Bear Creek Valley, Chestnut Ridge, and Parts of Bethel Valley on the U.S. Department of Energy Oak Ridge Reservation. (Y/TS881/R5).

BWXT. 2003b. Results of Calendar Year 2001 Monitoring Well Inspection and Maintenance Program, Y-12 National Security Complex, Oak Ridge, Tennessee. Prepared by the Y-12 Environment, Safety, and Health Division (Y/TS-1889).

BWXT, 2003c. Y-12 Groundwater Protection Program Monitoring Optimization Plan for Groundwater Monitoring Wells at the U.S. Department of Energy Y-12 National Security Complex, Oak Ridge, Tennessee. Prepared by Elvado L.L.C. (Y/SUB/03-021559/R2). 
BWXT. 2004b. Results of Calendar Year 2002 Monitoring Well Inspection and Maintenance Program, Y-12 National Security Complex, Oak Ridge, Tennessee. Prepared by the Y-12 Environment, Safety, and Health Division (Y/TS-1993).

BWXT. 2006a. Results of Calendar Year 2003 Monitoring Well Inspection and Maintenance Program, Y-12 National Security Complex, Oak Ridge, Tennessee. Prepared by the Y-12 Environment, Safety, and Health Division (Y/TS-2011)

BWXT. 2006b, Y-12 Groundwater Protection Program Monitoring Well Inspection and Maintenance Plan. Prepared by the Y-12 National Security Complex, Oak Ridge, Tennessee 37831 (Y/TS-1215/R3).

Driscoll, F.G. 1986. Groundwater and Wells. Second Edition. Johnson Division, St. Paul, Minnesota.

Lockheed Martin Energy Systems, Inc. 1996. Monitoring Well Inspection and Maintenance Plan, Y-12 Plant, Oak Ridge, Tennessee (Revised). Prepared by the Y-12 Environment, Safety, and Health Organization (Y/TS-1215).

Martin Marietta Energy Systems, Inc. (MMES). 1991. Monitor Well Inspection and Maintenance Plan for the Department of Energy Y-12 Plant, Oak Ridge, Tennessee. Prepared by HSW Environmental Consultants, Inc. (Y/SUB/01-YP507C/5).

MMES. 1994. Monitor Well Inspection and Maintenance Plan, Y-12 Plant, Oak Ridge, Tennessee (Revised). Prepared by the Y-12 Environment, Safety, and Health Organization (Y/TS1215). 
Y/TS-1215/R4

Monitoring Well Inspection and Maintenance Plan

\section{APPENDIX A: FIGURES}


Y/TS-1215/R4

This page intentionally left blank

A-2 


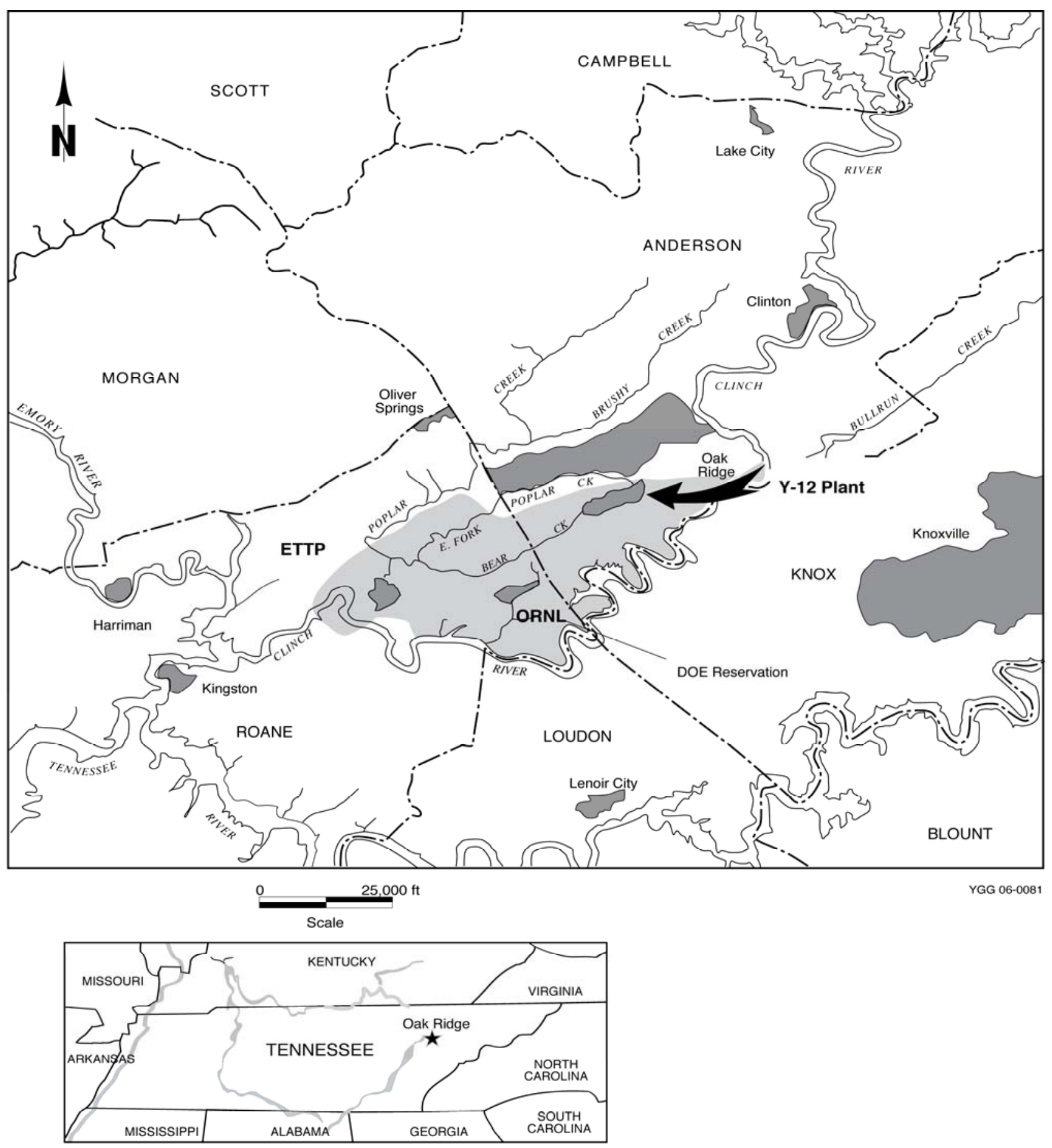

Fig. 1. Generalized location of the Y-12 National Security Complex. 
Y/TS-1215/R4

Monitoring Well Inspection and Maintenance Plan

A-4 


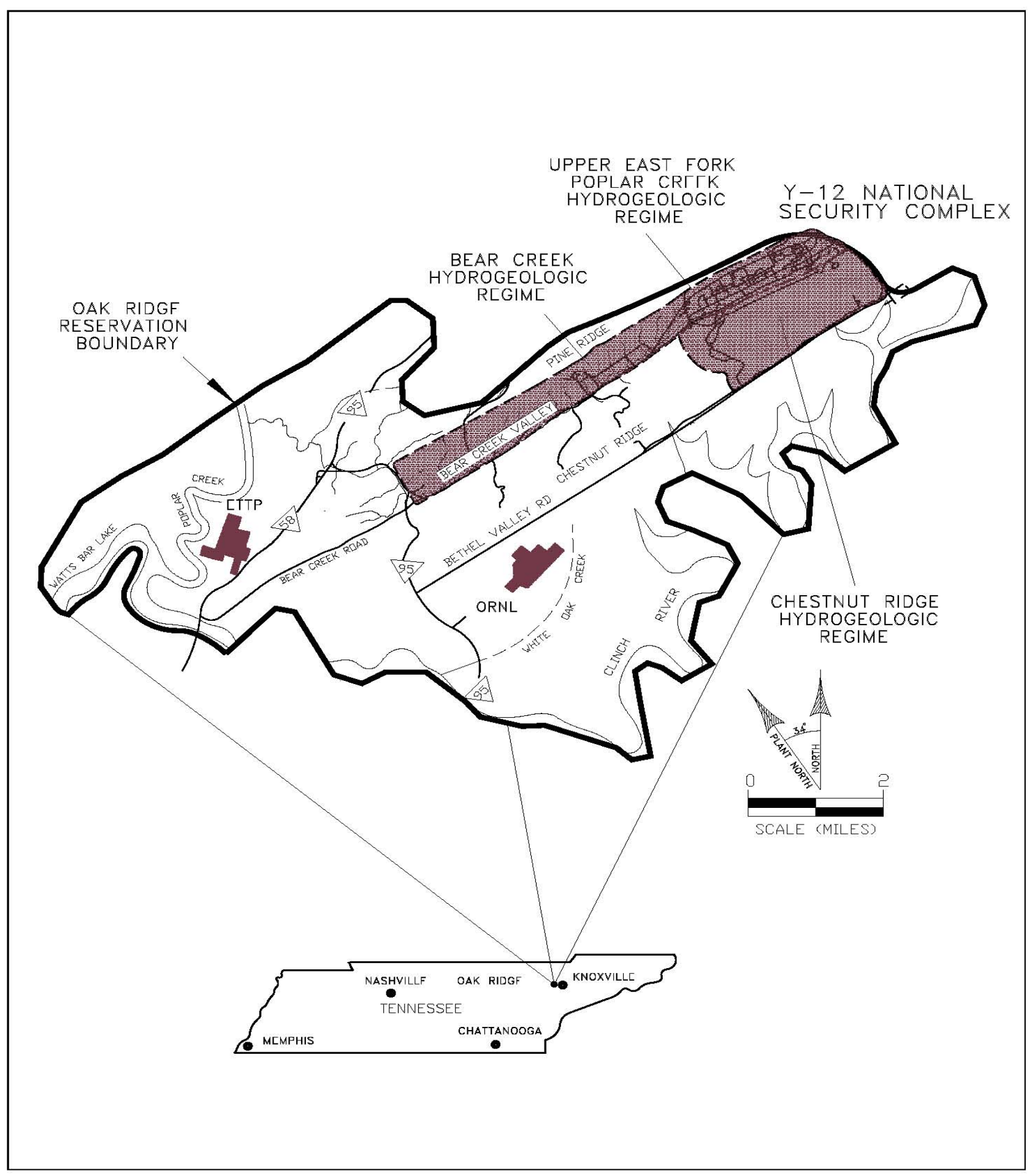

Fig. 2. Hydrogeologic regimes at the Y-12 National Security Complex. 
Y/TS-1215/R4

Monitoring Well Inspection and Maintenance Plan

A-6 


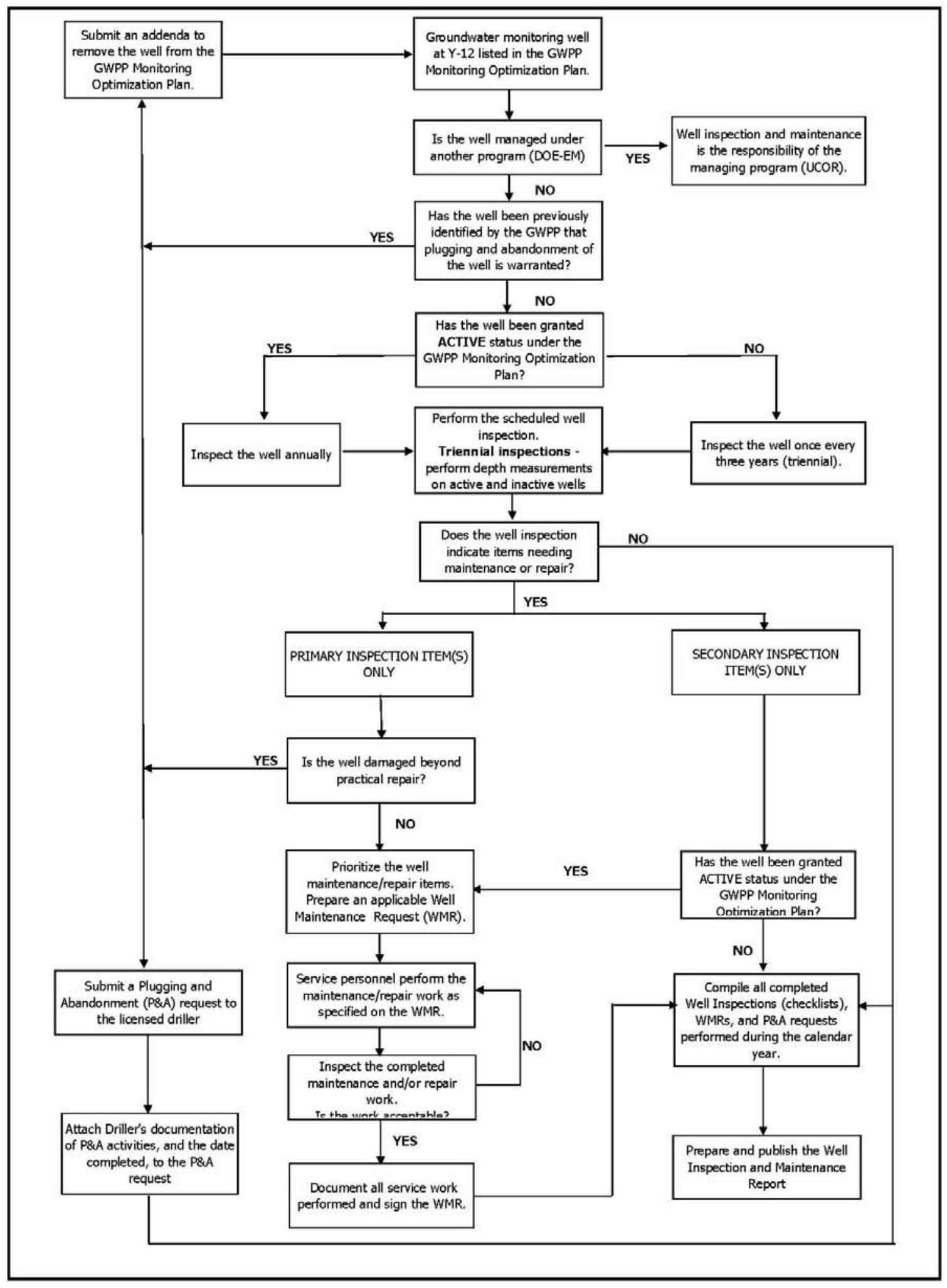

Fig. 3. Y-12 GWPP Monitoring Well Inspection and Maintenance Program 
Y/TS-1215/R4

Monitoring Well Inspection and Maintenance Plan

A-8 


\section{APPENDIX B: WELL COMPONENT SPECIFICATIONS}


This page intentionally left blank 

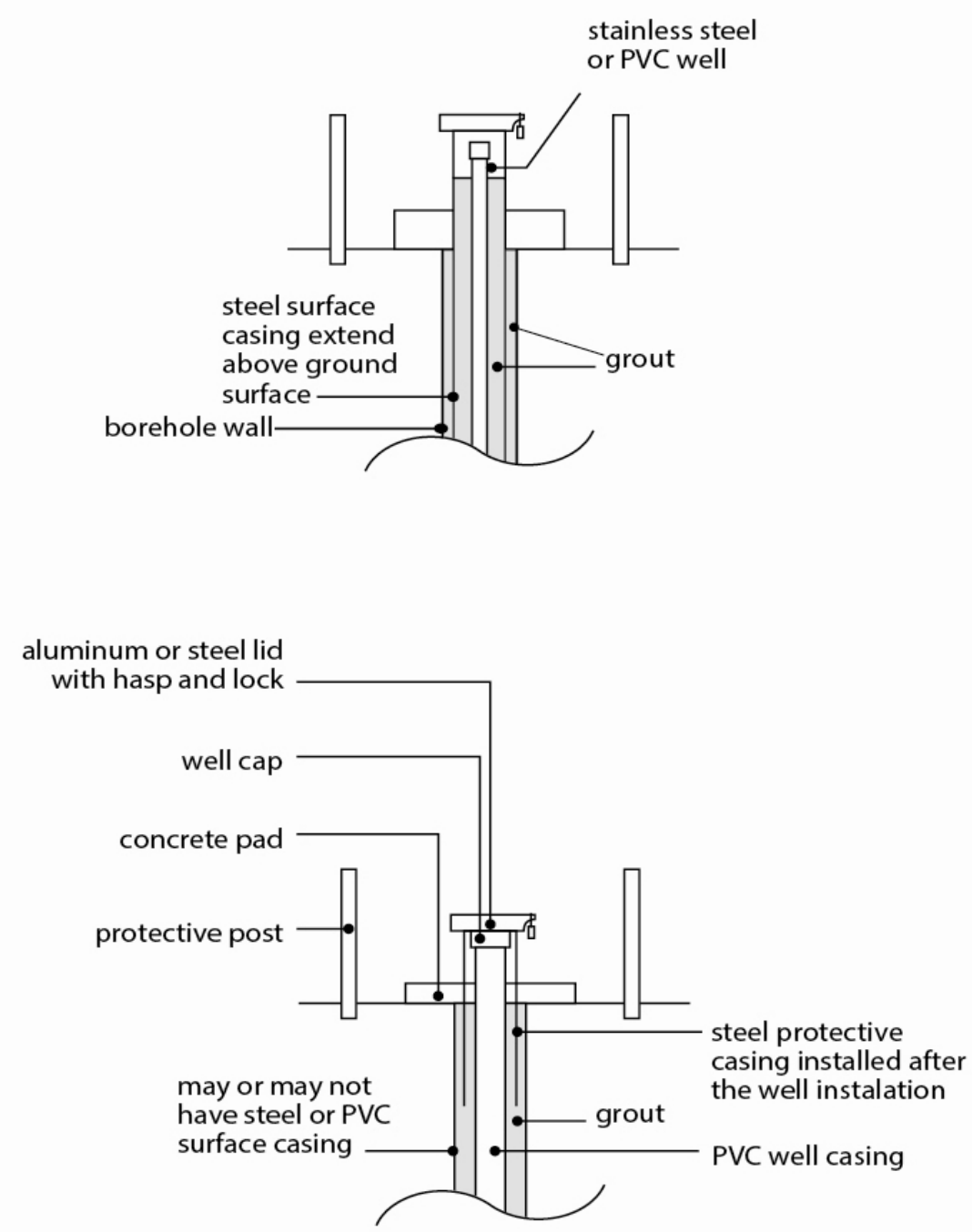

\section{Unconsolidated Zone}

Note: Older generation PVC wells and PVC piezometers/drivepoint at

Y-12 do not have a steel protective casing

Not To Scale

YGG 06-0075R2

Fig. 4. Generalized schematic of outer protective surface casing for PVC and stainless steel wells in unconsolidated and bedrock zone. 
Y/TS-1215/R4

Monitoring Well Inspection and Maintenance Plan

B-4 


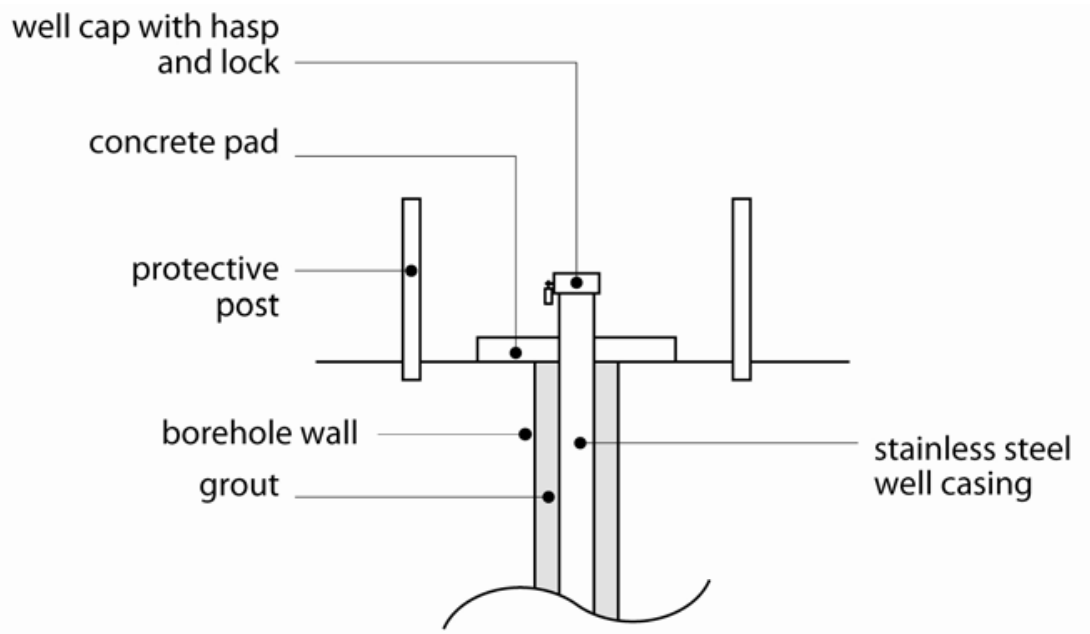

Unconsolidated Zone Well

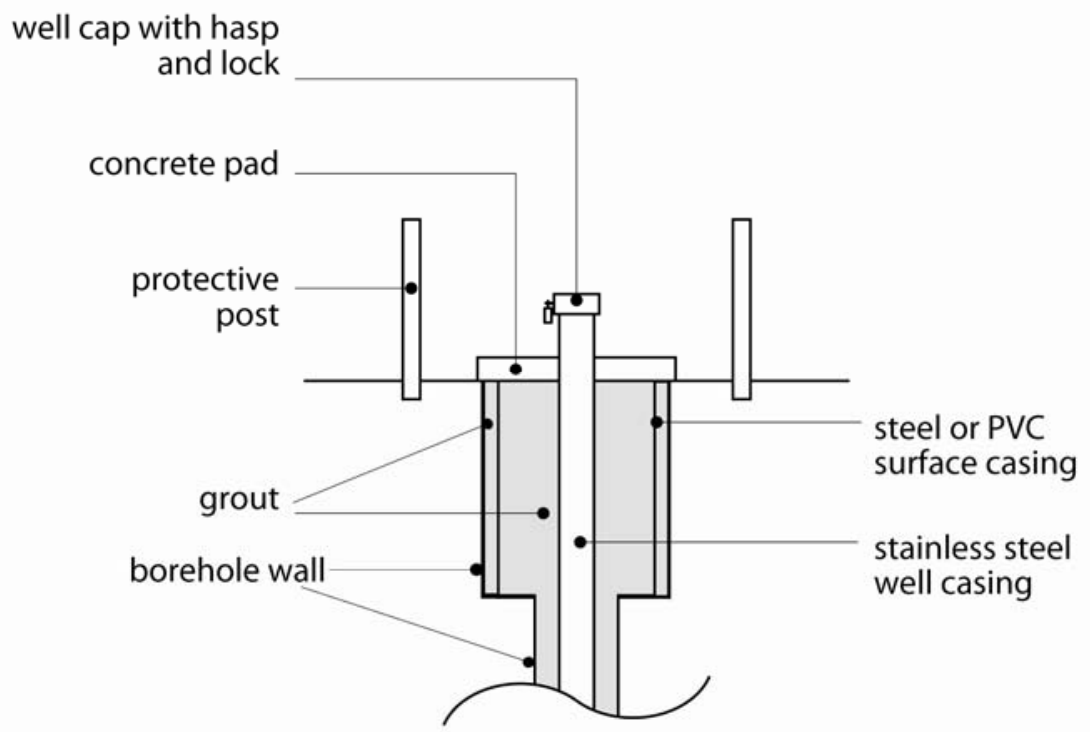

Bedrock Zone Well

Note: Not To Scale

YGG 06-0076R1

Fig. 5. Generalized schematic of stainless steel cased wells with screened intervals. 
Y/TS-1215/R4

Monitoring Well Inspection and Maintenance Plan

B-6 


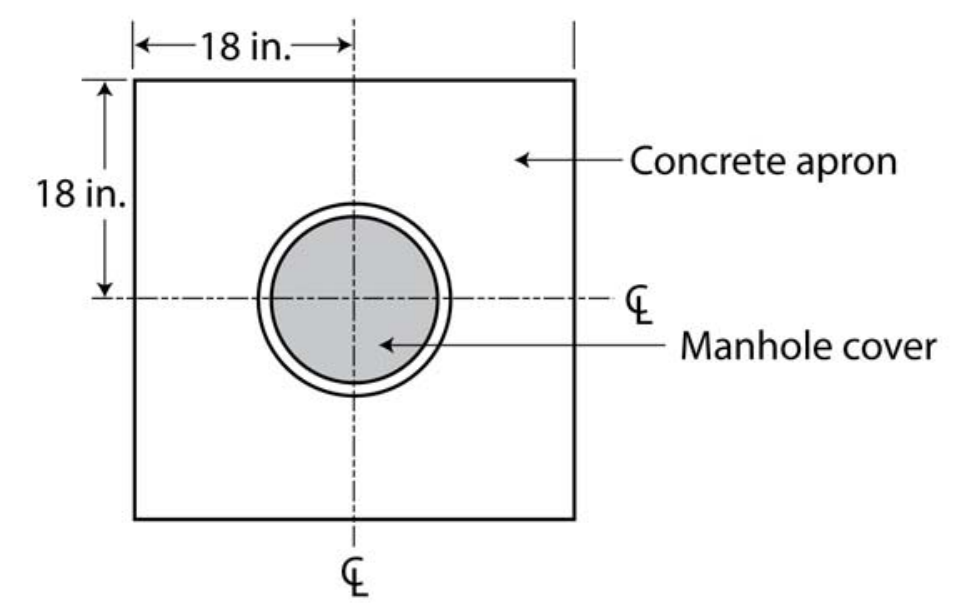

Plan View

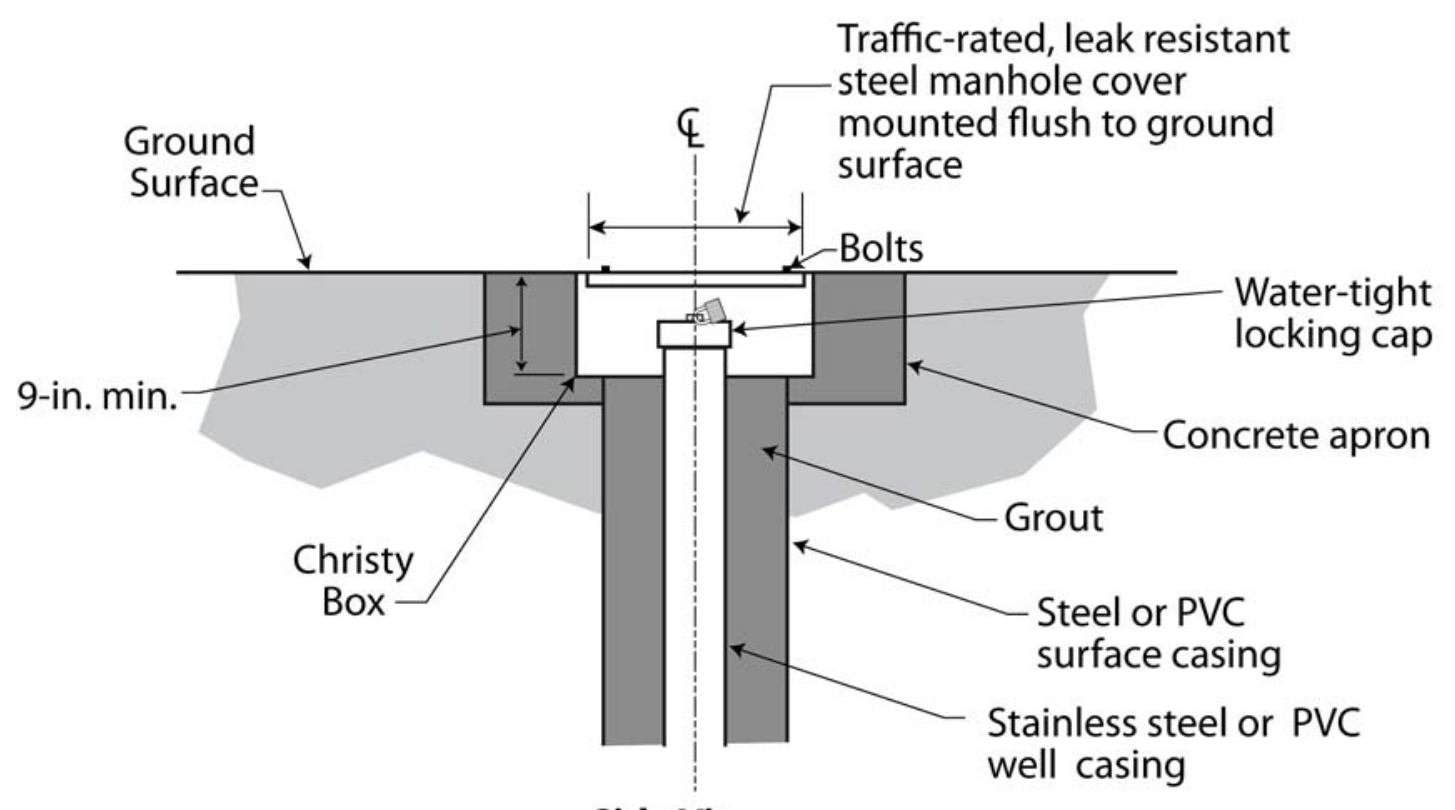

Side View

YGG 06-0080R1

Fig. 6. Generalized schematic for wells completed with flush-mount Christy box. 
Y/TS-1215/R4

Monitoring Well Inspection and Maintenance Plan

B-8 

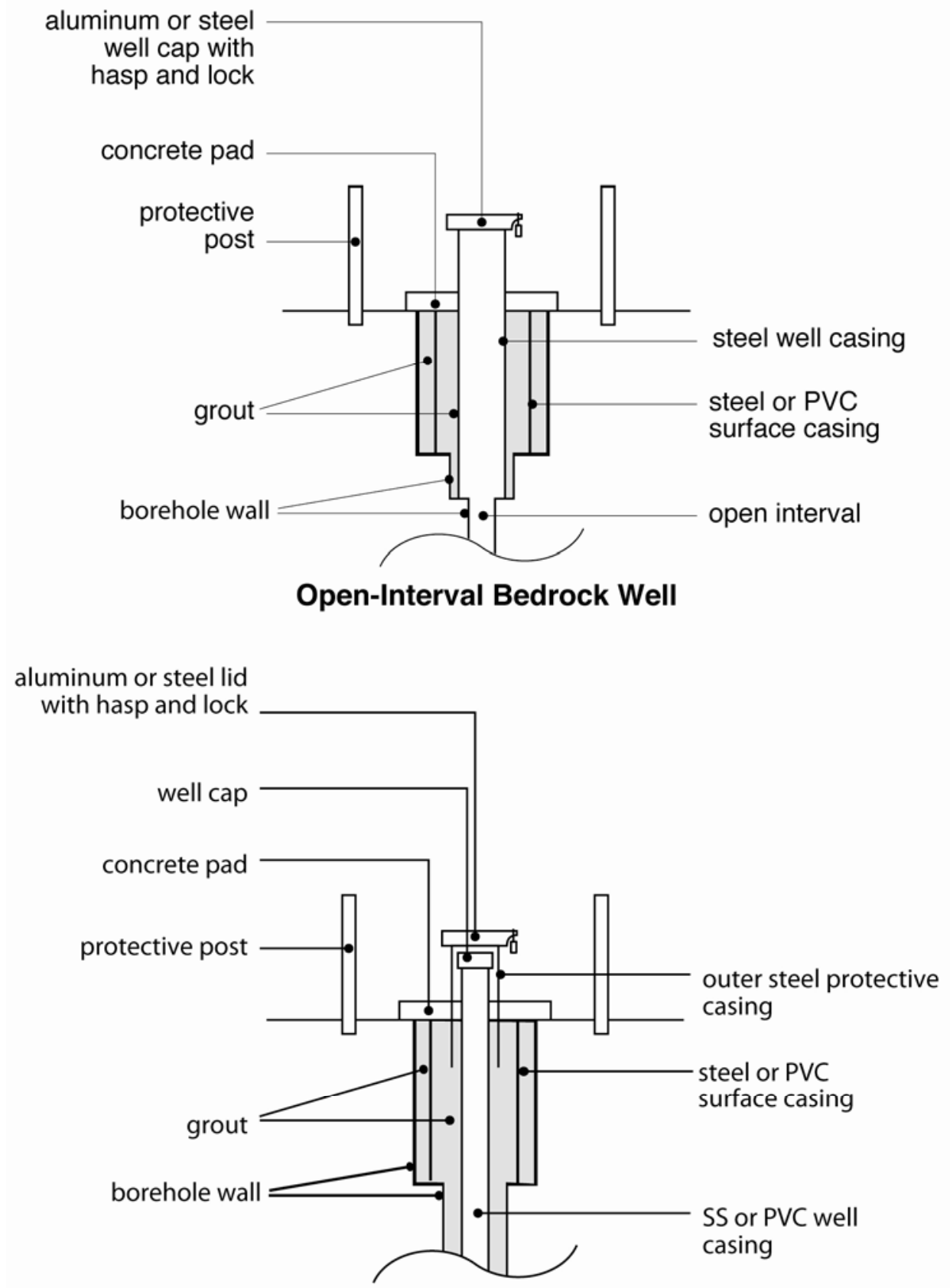

Bedrock Zone

Note: Not To Scale

YGG 06-0077R1

Fig. 7. Generalized schematic of steel cased wells with an open monitoring interval in bedrock. 
Y/TS-1215/R4

Monitoring Well Inspection and Maintenance Plan

B-10 


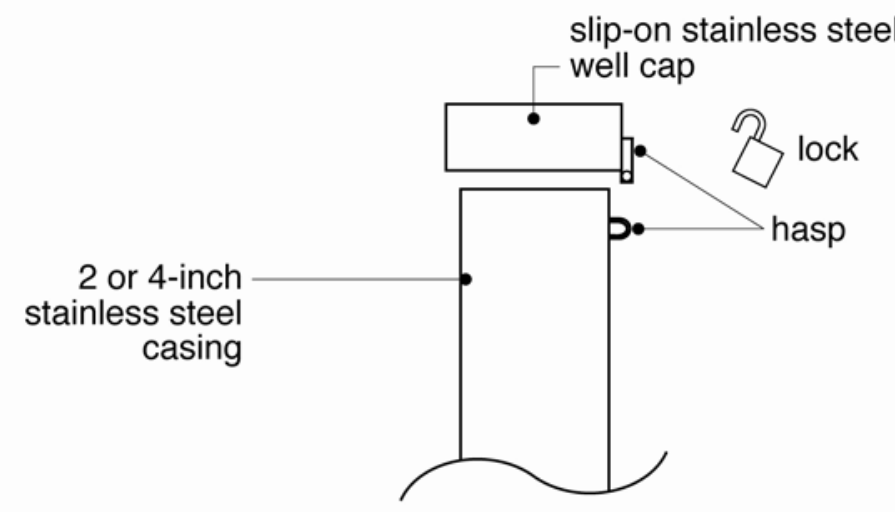

\section{Stainless Steel (SS) Cased Wells}

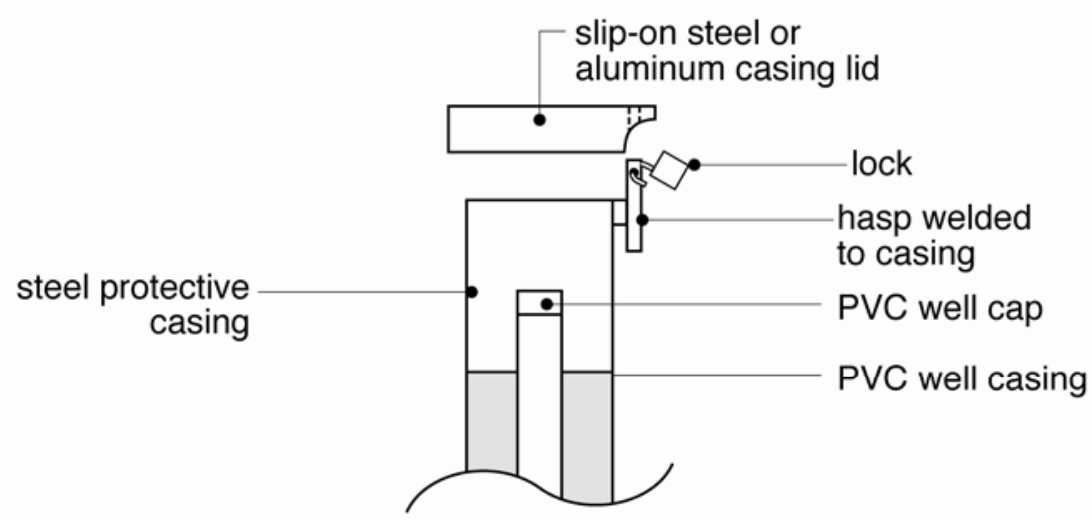

PVC Cased Wells with Steel Protective Casing

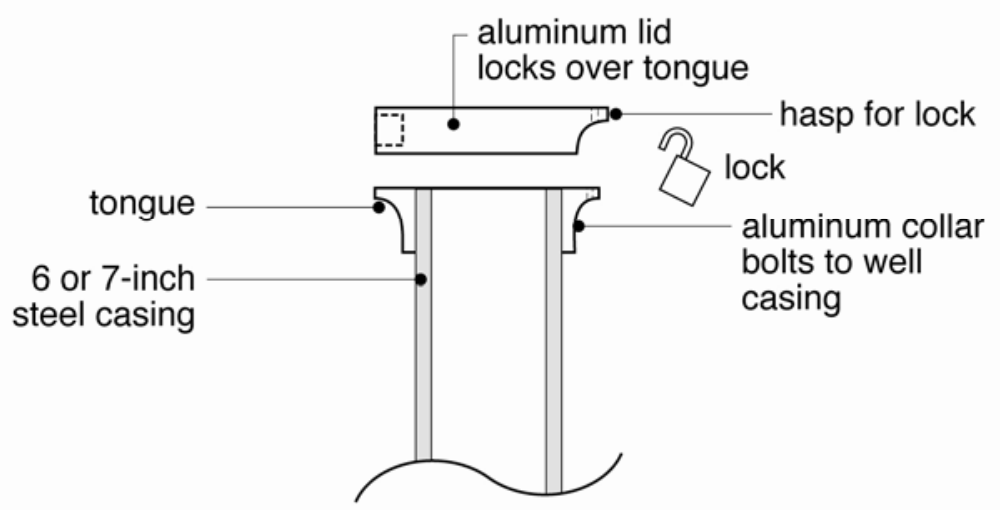

\section{Steel Cased Wells}

Note: Not To Scale

YGG 06-0078R1

Fig. 8. Generalized schematics of typical well-head configurations with cap, hasp, and lock. 
Y/TS-1215/R4

Monitoring Well Inspection and Maintenance Plan

B-12 

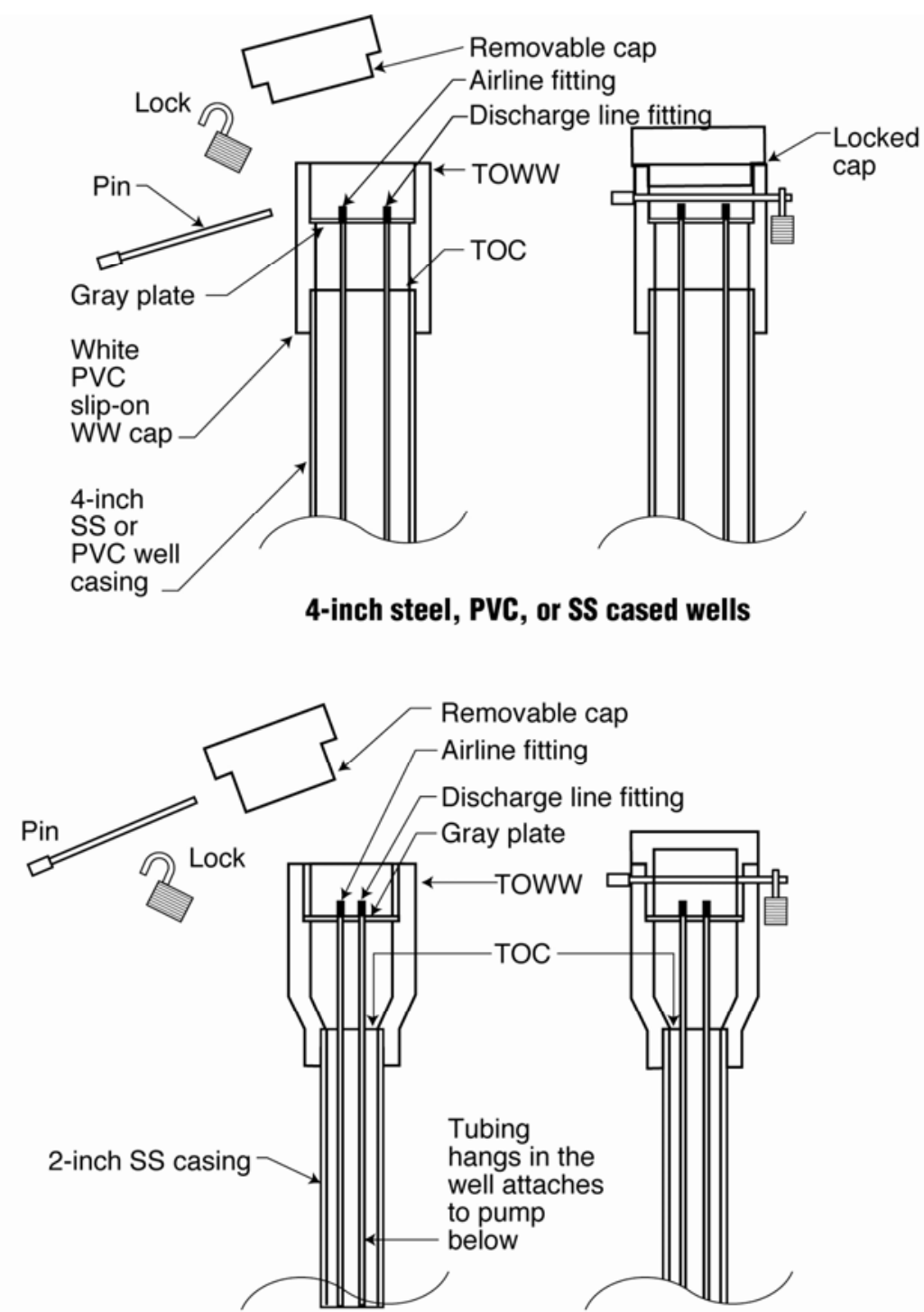

2-inch PVC or SS cased wells

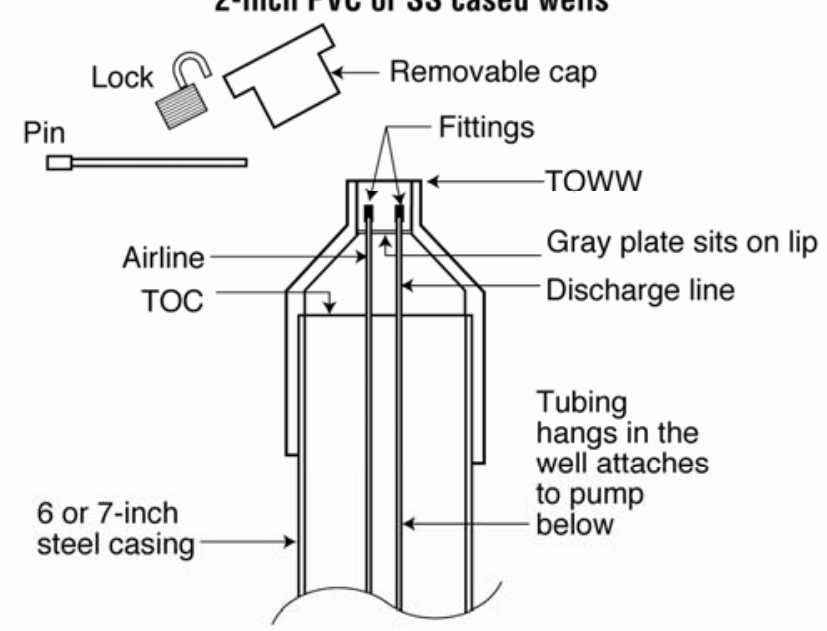

\section{6, 7 and 10 -inch Steel cased wells}

YGG 06-0079R1

Fig. 9. Schematic of different configurations with Well Wizards. 
Y/TS-1215/R4

Monitoring Well Inspection and Maintenance Plan

B-14 

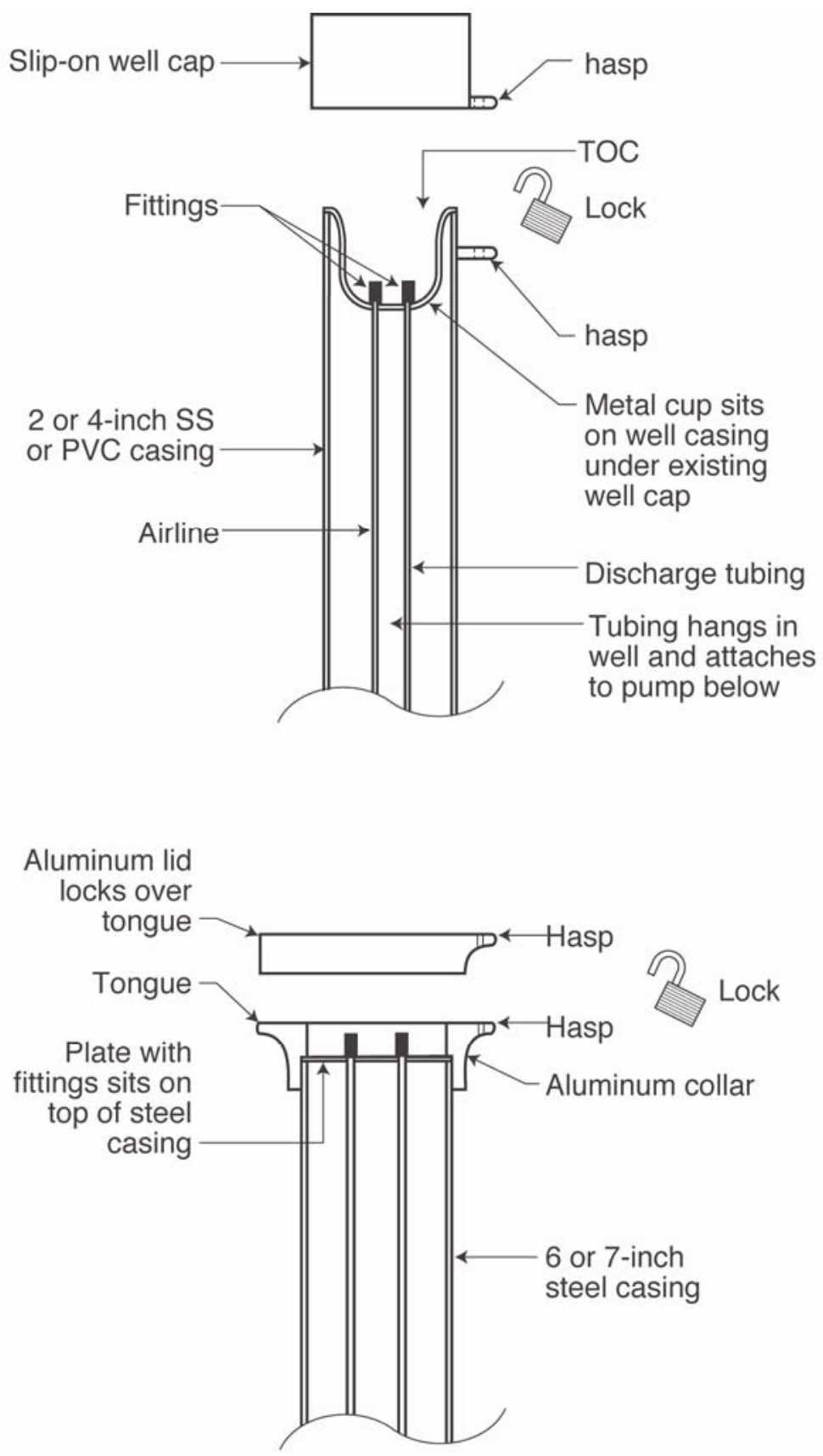

Fig. 10. Well Wizards with low clearance caps. 
Y/TS-1215/R4

Monitoring Well Inspection and Maintenance Plan

B-16 


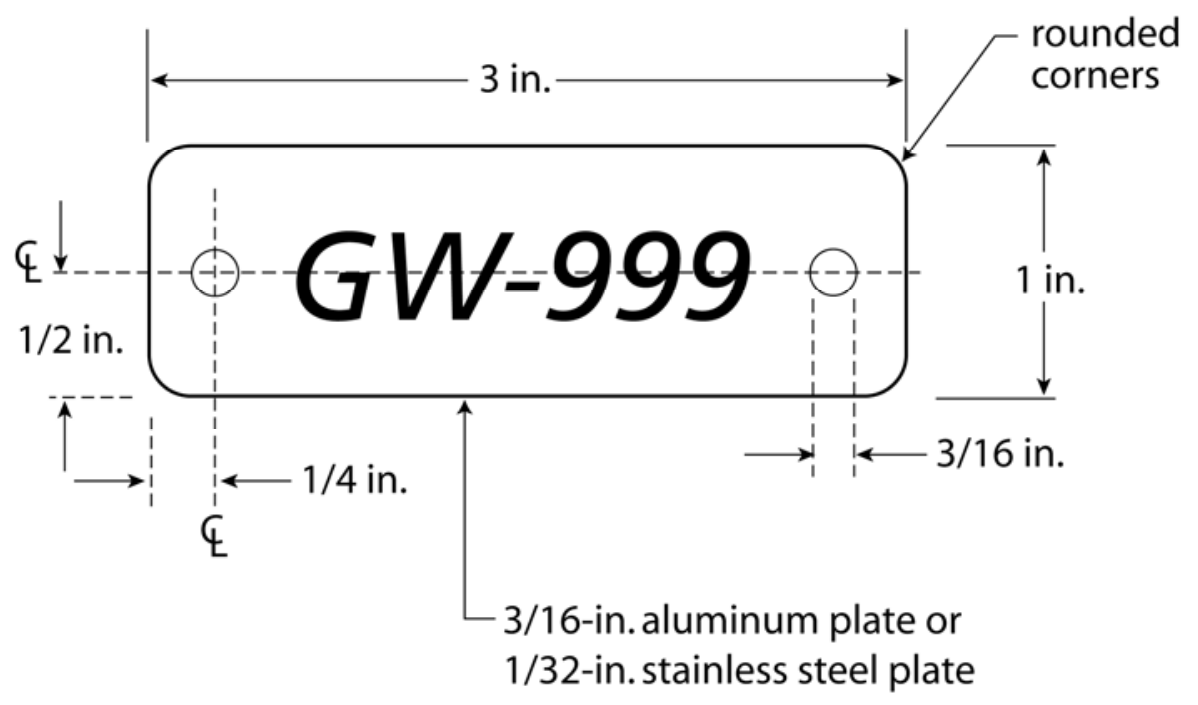

Numbers must be stamped or eched into the plate, and then blackened for higher visibility

Fig. 11. Typical well identification tag. 
Y/TS-1215/R4

Monitoring Well Inspection and Maintenance Plan

B-18 


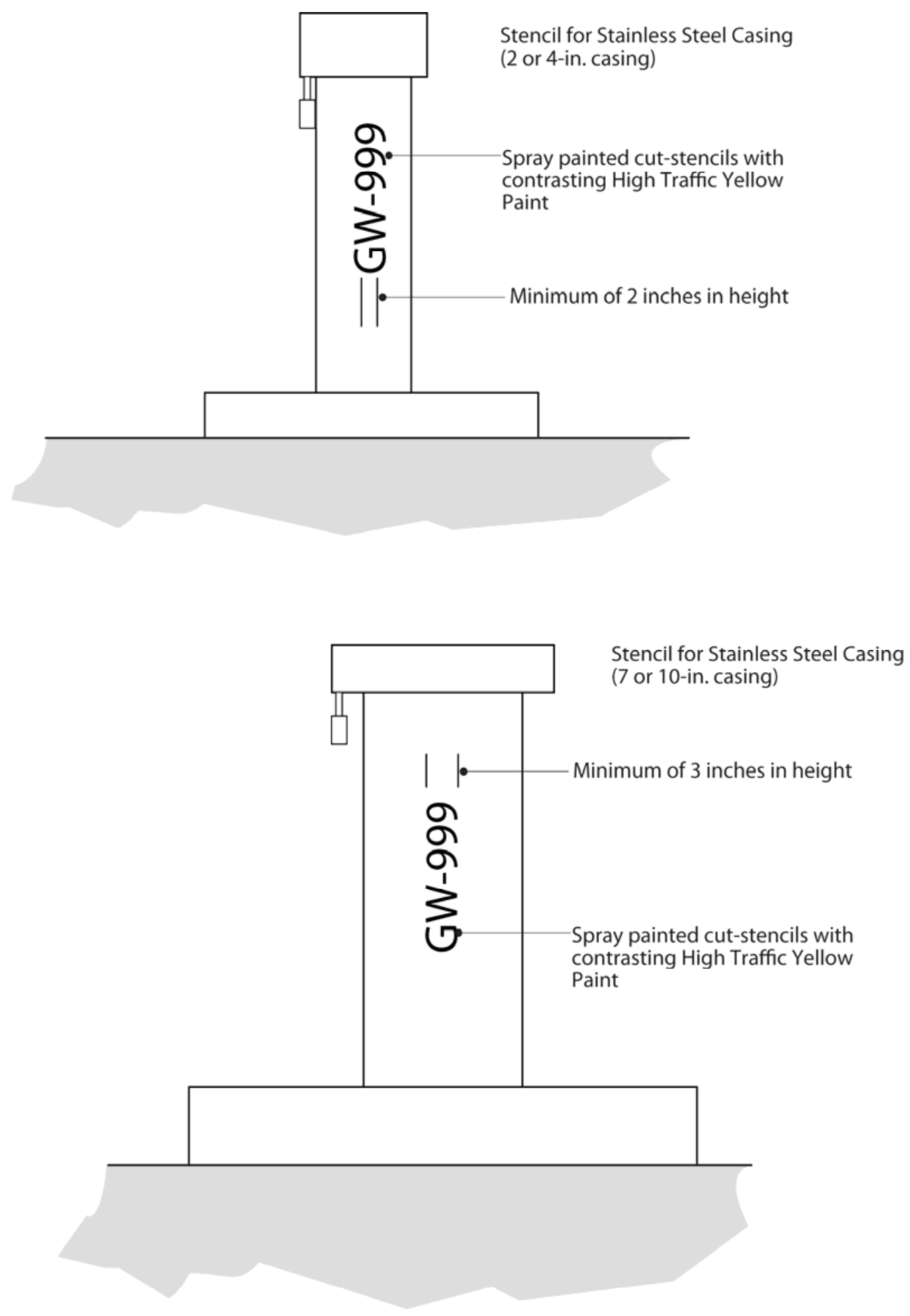

Fig. 12. Typical casing stencils. 
Y/TS-1215/R4

Monitoring Well Inspection and Maintenance Plan 


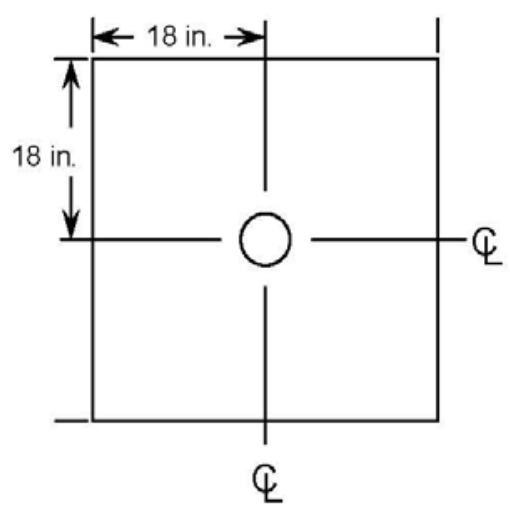

PLAN VIEW

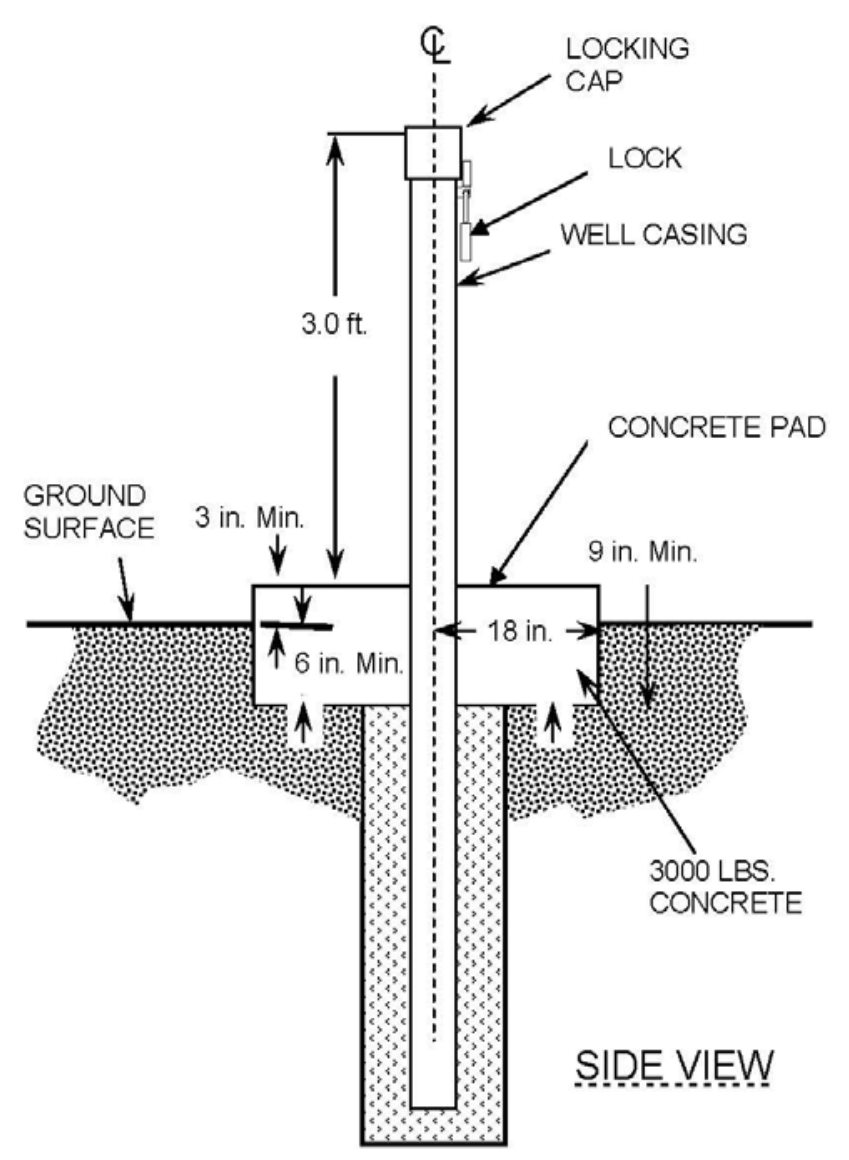

Fig. 13. Typical concrete pad. 
Y/TS-1215/R4

Monitoring Well Inspection and Maintenance Plan 


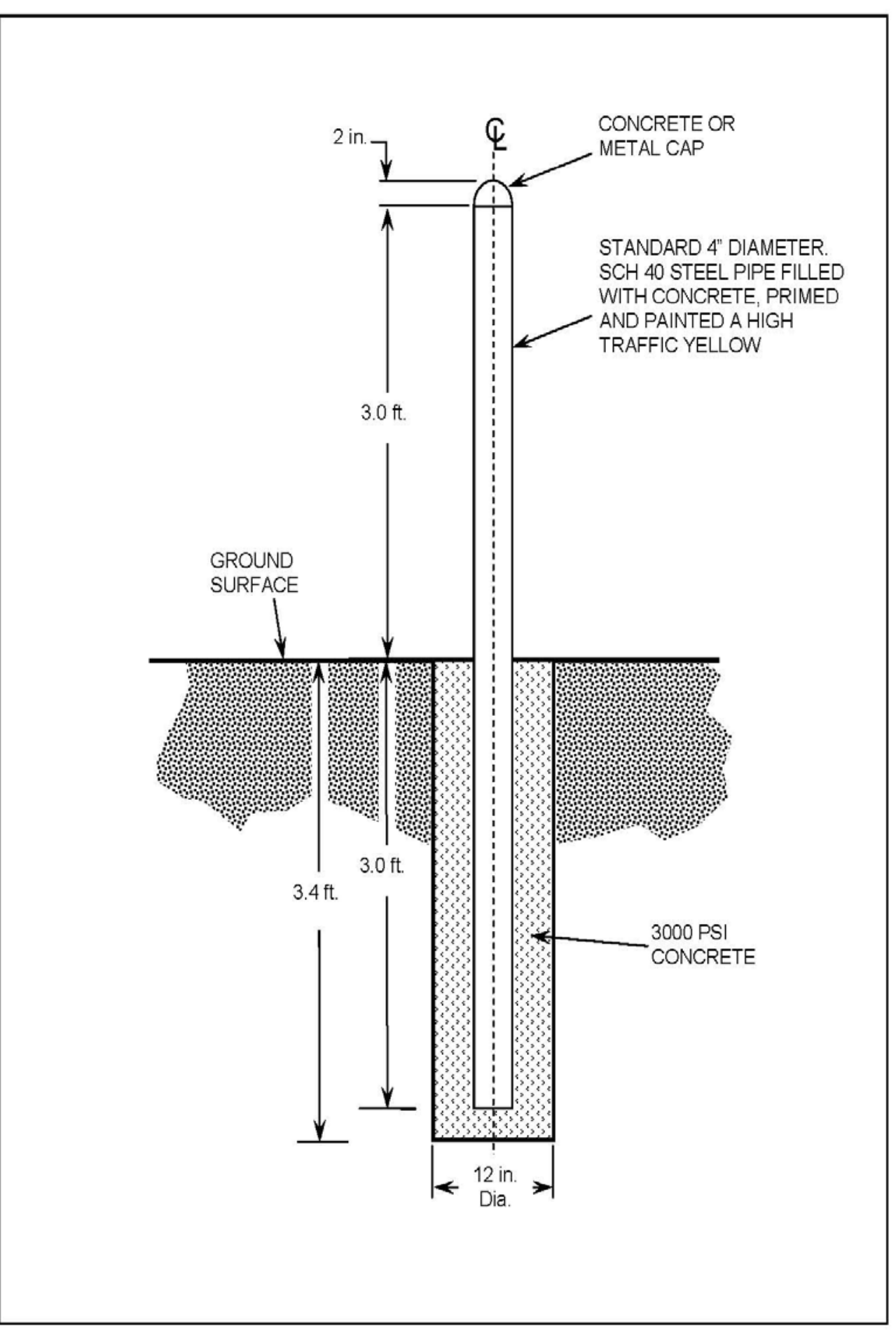

Fig. 14. Typical guard post. 
Y/TS-1215/R4

Monitoring Well Inspection and Maintenance Plan 


\section{APPENDIX C: WELL INSPECTION CHECKLIST FORMS}


This page intentionally left blank 


\section{Y-12 PLANT GROUNDWATER PROTECTION PROGRAM WELL INSPECTION CHECKLIST (Annual Inspection) INSPECTION NO:}

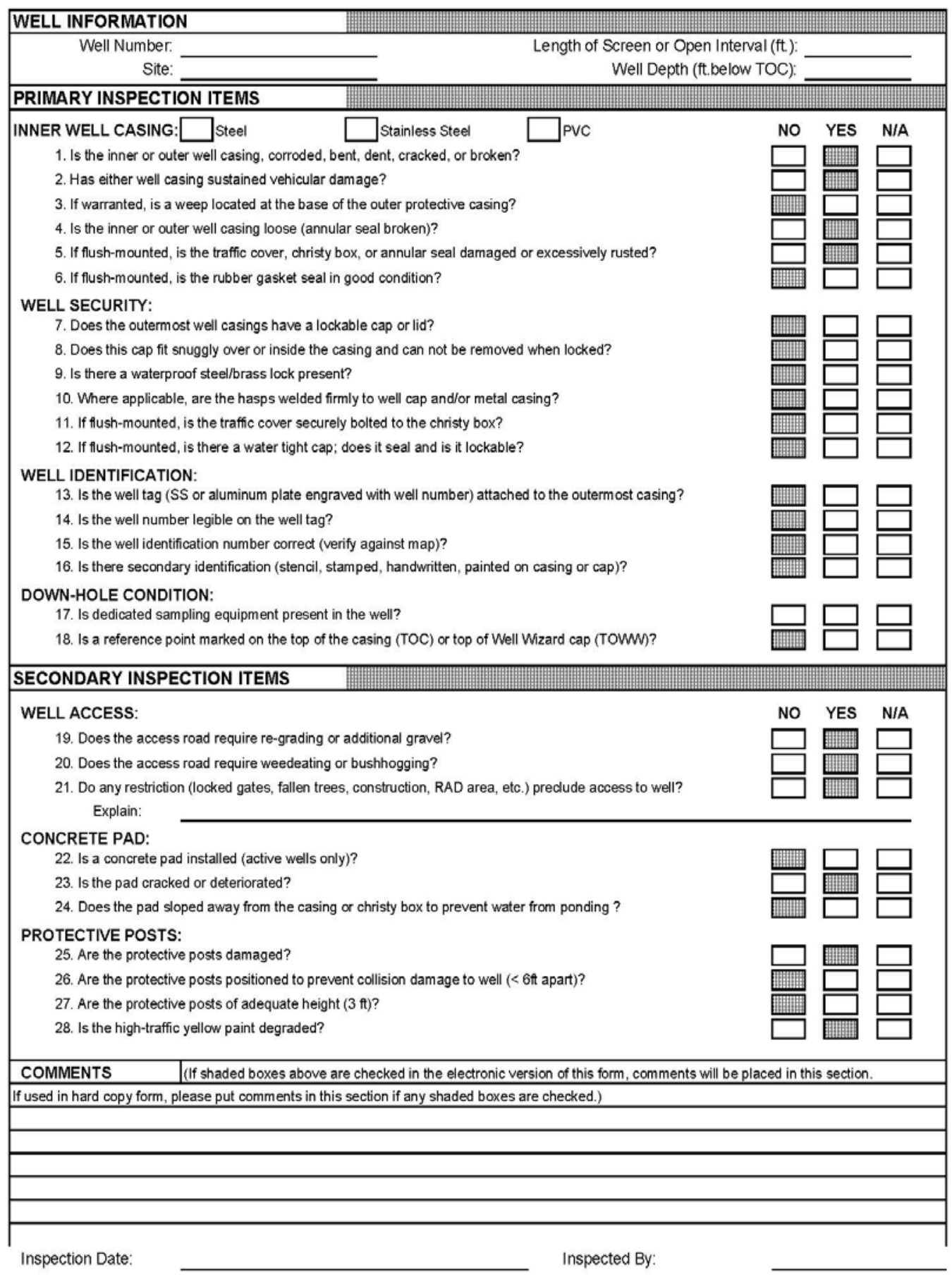


This page intentionally left blank 


\section{Y-12 PLANT GROUNDWATER PROTECTION PROGRAM WELL INSPECTION CHECKLIST (Triennial Inspection) INSPECTION NO:}

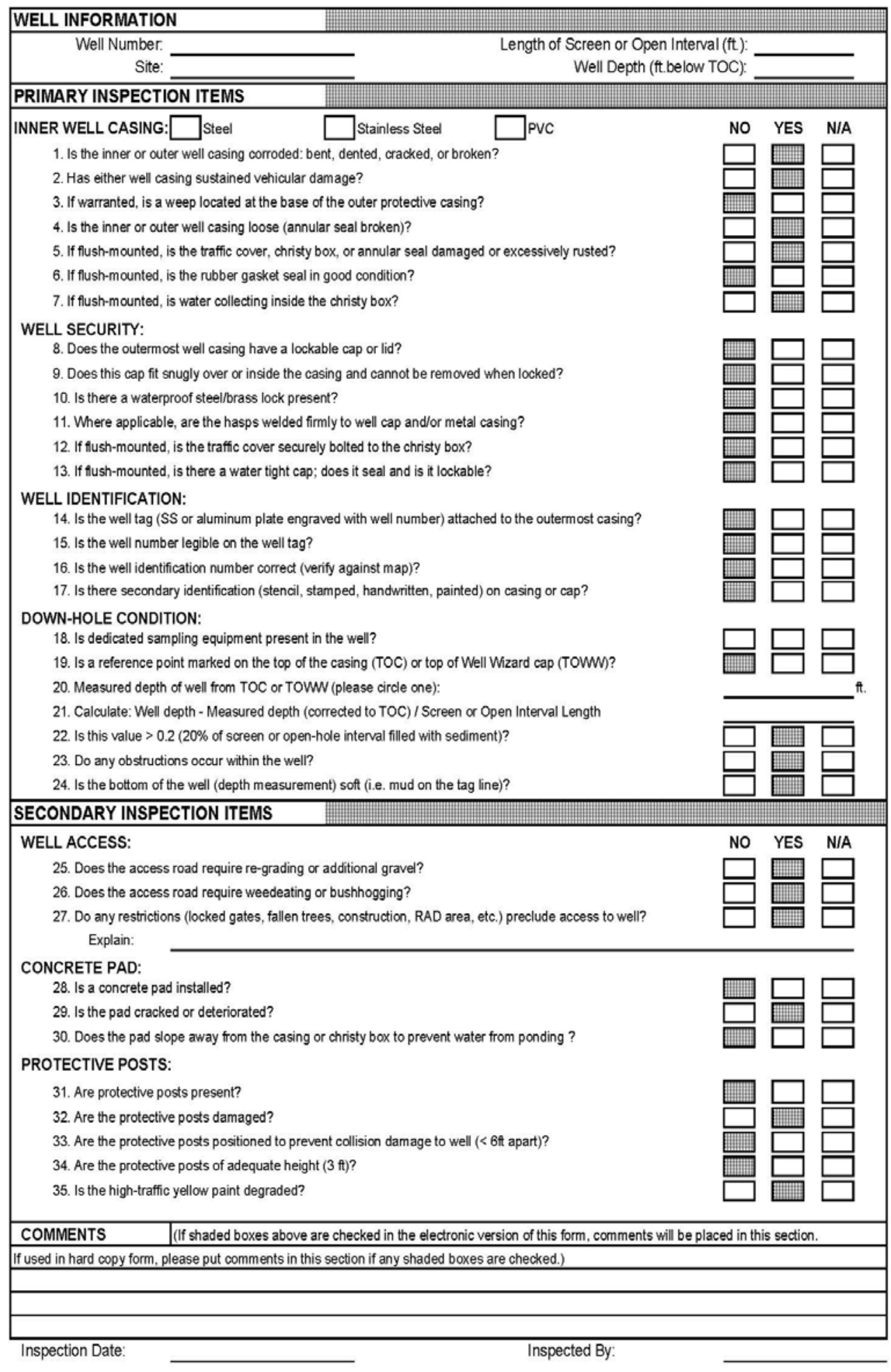


This page intentionally left blank 


\section{APPENDIX D: \\ WELL MAINTENANCE REQUEST FORM PLUGGING AND ABANDONMENT REQUEST FORM}


This page intentionally left blank

D-2 


\section{Y-12 GROUNDWATER PROTECTION PROGRAM WELL MAINTENANCE REQUEST (WMR)}

WMR NUMBER:

WELL INSPECTION NO:

\begin{tabular}{|l}
\hline WELL NUMBER: \\
\hline WELL INSPECTION DATE: \\
\hline MAINTENANCE WORK REQUESTED : \\
$\square$ Build/Repair Concrete Pad \\
$\square$ Install/Paint Protective Posts \\
$\square$ Repair/Replace Hasp \\
$\square$ Remove/Replace Lock \\
$\square$ Well Re-development \\
$\square$ Repair/Replace Christy Box
\end{tabular}

LOCATION:

INSPECTED BY:

DESCRIPTION OF WORK :

$\square$ Replace gasket seals or bolts on Traffic Cover

$\square$ Replace Well Cap or Lid

$\square$ Extend or Repair Well Casing

$\square$ Install/Replace Well Identification Tag

$\square$ Well Access (weedeating, mowing, re-grading)

$\square$ Miscellaneous Labor

(retrieval of items in well, weepholes, etc)

$\square$ Other (describe below)

DATE WMR SUBMITTED

JHA\#

MAINTENANCE PERFORMED BY (name and badge \#):

DATE WORK COMPLETED:

Service Notification or RFE\#

COMMENTS ON MAINTENANCE WORK PERFORMED:

WORK INSPECTED BY

DATE INSPECTED

INSPECTION COMMENTS:

APPROVED BY:

DATE: 
This page intentionally left blank 


\section{Y-12 GROUNDWATER PROTECTION PROGRAM PLUGGING AND ABANDONMENT (P\&A) REQUEST}

P\&A REQUEST NUMBER:

\begin{tabular}{|l|l|}
\hline WELL NUMBER: & SITE: \\
\hline INSPECTION NUMBER: & INSPECTED BY: \\
\hline REASON FOR PLUGGING AND ABANDONMENT: & \\
$\square$ & Well Casing Damage/Deterioration \\
$\square$ & Annular Grout Deterioration \\
$\square$ & Loss of Well Security \\
$\square$ & Downhole Conditions \\
$\square$ & Site Construction, Closure, or Operation \\
COMMENTS/EXPLANATION FOR P\&A: & \\
\hline
\end{tabular}

P\&A REQUEST SUBMITTED BY: DATE SUBMITTED:

P\&A REQUEST SUBMITTED BY:
\begin{tabular}{|l|l|}
\hline & \\
\hline CONTRACTOR PERFORMING P\&A ACTIVITIES: & \\
\hline & P\&A DOCUMENTATION ATTACHED?
\end{tabular}

APPROVED BY: DATE COMPLETED: 
This page intentionally left blank 


\section{APPENDIX E: INSPECTED WELLS}


This page intentionally left blank 


\section{Inspected Wells}

\begin{tabular}{|c|c|c|c|}
\hline $\begin{array}{c}\text { Well } \\
\text { Number }\end{array}$ & Location & $\begin{array}{l}\text { Reference } \\
\text { Tag Depth }\end{array}$ & $\begin{array}{c}\text { Well } \\
\text { Status/Function }\end{array}$ \\
\hline 1082 & Oak Ridge Sludge Farm & 55.00 & ActiveML \\
\hline 1084 & Oak Ridge Sludge Farm & 148.60 & Active/ML \\
\hline 1090 & UNC Site & 98.02 & UCOR-Active/WL \\
\hline $54-2 A$ & Y-12 Plant Site & 26.15 & Inactive \\
\hline $55-1 A$ & Y-12 Grid Well B2 & 19.22 & Active $M$ L \\
\hline $55-1 \mathrm{~B}$ & Y-12 Plant Site & 38.70 & Inactive \\
\hline $55-1 \mathrm{C}$ & Y-12 Grid Well B2 & 76.60 & Inactive \\
\hline $55-2 A$ & Y-12 Plant Site & 13.98 & Active \\
\hline $55-2 B$ & Y-12 Grid Well B3 & 27.69 & Active \\
\hline $55-2 \mathrm{C}$ & Y-12 Grid Well B3 & 76.00 & Active \\
\hline $55-3 A$ & Y-12 Plant Site & 14.25 & Active/ML \\
\hline $55-3 B$ & Y-12 Plant Site & 37.98 & Active \\
\hline $55-3 \mathrm{C}$ & Y-12 Plant Site & 77.43 & Active \\
\hline $55-6 \mathrm{~A}$ & Y-12 Grid Well C2 & 12.77 & ActiveML \\
\hline $56-1 \mathrm{~A}$ & Y-12 Plant Site & 18.95 & Active $M L$ \\
\hline $56-1 C$ & Y-12 Plant Site & 73.45 & Active \\
\hline $56-2 A$ & Y-12 Grid Well C3 & 15.03 & Active $M L$ \\
\hline $56-2 B$ & Y-12 Grid Well C3 & 38.63 & Active \\
\hline $56-2 \mathrm{C}$ & Y-12 Grid Well C3 & 77.03 & Active \\
\hline $56-3 A$ & Y-12 Plant Site & 17.92 & Active \\
\hline $56-3 B$ & Y-12 Plant Site & 30.85 & Active \\
\hline $56-3 \mathrm{C}$ & Y-12 Plant Site & 55.35 & Active \\
\hline $56-4 \mathrm{~A}$ & Y-12 Plant Site & 12.60 & Active \\
\hline $56-6 \mathrm{~A}$ & Y-12 Plant Site & 20.97 & Active \\
\hline $56-7 A$ & Y-12 Plant Site & 21.13 & Inactive \\
\hline $56-8 \mathrm{~A}$ & Y-12 Plant Site & 25.44 & Active $M L$ \\
\hline $58-2 \mathrm{~A}$ & Y-12 Plant Site & 9.78 & Inactive \\
\hline $59-1 \mathrm{~A}$ & Building 9202 & 13.10 & Inactive \\
\hline $59-1 \mathrm{~B}$ & Building 9202 & 36.80 & Inactive \\
\hline $59-1 \mathrm{C}$ & Building 9202 & 75.46 & Inactive \\
\hline $60-1 \mathrm{~A}$ & Y-12 Plant Site & 23.10 & Active/ML \\
\hline $60-1 \mathrm{~B}$ & Y-12 Plant Site & 29.10 & Inactive \\
\hline $\mathrm{CH}-143$ & Kerr Hollow Quarry & 58.27 & Inactive \\
\hline $\mathrm{CH}-157$ & Chestnut Ridge Sediment Disposal Basin & 538.73 & Inactive \\
\hline $\mathrm{CH}-185$ & Rogers Quarry & 839.95 & Inactive \\
\hline $\mathrm{CH}-189$ & Rogers Quarry & 764.43 & Inactive \\
\hline GW-001 & Oil Landfarm WMA & 27.56 & Active $M L$ \\
\hline GW-006 & Oil Landfarm WMA & 51.08 & Active \\
\hline GW-008 & Oil Landfarm WMA & 26.69 & UCOR-Active/ML \\
\hline GW-010 & Oil Landfarm WMA & 16.50 & UCOR-Active/ML \\
\hline GW-011 & Oil Landfarm WMA & 43.22 & Inactive \\
\hline GW-012 & Oil Landfarm WMA & 19.20 & UCOR-Active/ML \\
\hline GW-013 & Oil Landfarm WMA & 7.06 & Inactive \\
\hline GW-014 & Bear Creek Burial Grounds WMA & 14.50 & UCOR-Active/SMPLML \\
\hline GW-015 & Bear Creek Burial Grounds WMA & 11.69 & Inactive \\
\hline GW-016 & Bear Creek Burial Grounds WMA & 18.88 & ActiveML \\
\hline GW-017 & Bear Creek Burial Grounds WMA & 65.35 & Inactive \\
\hline GW-018 & Bear Creek Burial Grounds WMA & 21.71 & Inactive \\
\hline
\end{tabular}




\section{Inspected Wells}

\begin{tabular}{|c|c|c|c|}
\hline $\begin{array}{c}\text { Well } \\
\text { Number }\end{array}$ & Location & $\begin{array}{l}\text { Reference } \\
\text { Tag Depth }\end{array}$ & $\begin{array}{c}\text { Well } \\
\text { Status/Function }\end{array}$ \\
\hline GW-040 & Bear Creek Burial Grounds WMA & 33.73 & Inactive \\
\hline GW-041 & Bear Creek Burial Grounds WMA & 42.48 & Active $M$ L \\
\hline GW-042 & Bear Creek Burial Grounds WMA & 32.31 & Inactive \\
\hline GW-045 & Bear Creek Burial Grounds WMA & 17.66 & Inactive \\
\hline GW-046 & Bear Creek Burial Grounds WMA & 23.85 & UCOR-Active $M$ L \\
\hline GW-047 & Bear Creek Burial Grounds WMA & 26.97 & Active $M$ L \\
\hline GW-052 & Bear Creek Burial Grounds WMA & 22.04 & Active $M L$ \\
\hline GW-053 & Bear Creek Burial Grounds WMA & 35.13 & Active $M L$ \\
\hline GW-054 & Bear Creek Burial Grounds WMA & 40.75 & Inactive \\
\hline GW-055 & Bear Creek Burial Grounds WMA & 22.89 & Inactive \\
\hline GW-056 & Exit Pathway - Traverse A & 59.21 & Inactive \\
\hline GW-057 & Exit Pathway - Traverse A & 25.17 & Active ML \\
\hline GW-058 & Bear Creek Burial Grounds WMA & 48.90 & Active \\
\hline GW-059 & Bear Creek Burial Grounds WMA & 27.65 & Active $M L$ \\
\hline GW-061 & Bear Creek Burial Grounds WMA & 28.09 & Inactive \\
\hline GW-062 & Oil Landfarm WMA & 54.13 & Inactive \\
\hline GW-064 & Oil Landfarm WMA & 55.07 & Inactive \\
\hline GW-065 & Oil Landfarm WMA & 36.89 & Active $\mathrm{ML}$ \\
\hline GW-066 & Oil Landfarm WMA & 59.24 & Inactive \\
\hline GW-067 & Oil Landfarm WMA & $\mathrm{NM}$ & Inactive \\
\hline GW-068 & Bear Creek Burial Grounds WMA & 86.10 & Active \\
\hline GW-069 & Bear Creek Burial Grounds WMA & 101.96 & UCOR-Active/WL \\
\hline GW-070 & Bear Creek Burial Grounds WMA & 142.13 & Inactive \\
\hline GW-071 & Bear Creek Burial Grounds WMA & 218.40 & UCOR-Active \\
\hline GW-072 & Bear Creek Burial Grounds WMA & 101.99 & Inactive \\
\hline GW-073 & Oil Landfarm WMA & 81.44 & Inactive \\
\hline GW-074 & Oil Landfarm WMA & 208.21 & Inactive \\
\hline GW-075 & Oil Landfarm WMA & 205.59 & UCOR-Active \\
\hline GW-077 & Bear Creek Burial Grounds WMA & 104.10 & UCOR-Active \\
\hline GW-078 & Bear Creek Burial Grounds WMA & 23.40 & UCOR-Active $M$ L \\
\hline GW-079 & Bear Creek Burial Grounds WMA & 67.70 & UCOR-Active \\
\hline GW-080 & Bear Creek Burial Grounds WMA & 33.00 & UCOR-Active $M L$ \\
\hline GW-081 & Bear Creek Burial Grounds WMA & 20.98 & Inactive \\
\hline GW-082 & Bear Creek Burial Grounds WMA & 38.45 & UCOR-Active/SMPLML \\
\hline GW-083 & Bear Creek Burial Grounds WMA & 33.14 & Inactive \\
\hline GW-084 & Oil Landfarm WMA & 29.92 & Active $M$ L \\
\hline GW-085 & Oil Landfarm WMA & 62.34 & Active \\
\hline GW-086 & Oil Landfarm WMA & 33.01 & Active $M L$ \\
\hline GW-089 & Bear Creek Burial Grounds WMA & 27.97 & Active \\
\hline GW-090 & Bear Creek Burial Grounds WMA & 18.81 & Active $\mathrm{ML}$ \\
\hline GW-091 & Bear Creek Burial Grounds WMA & 19.30 & Active ML \\
\hline GW-094 & Bear Creek Burial Grounds WMA & 119.21 & Inactive \\
\hline GW-095 & Bear Creek Burial Grounds WMA & 157.03 & Inactive \\
\hline GW-096 & Bear Creek Burial Grounds WMA & 56.38 & Inactive \\
\hline GW-097 & Oil Landfarm WMA & 23.86 & Active $\mathrm{ML}$ \\
\hline GW-097A & Oil Landfarm WMA & 24.15 & Inactive \\
\hline GW-098 & Oil Landfarm WMA & 105.65 & Active \\
\hline GW-100 & S-3 Site & 17.87 & Active $M L$ \\
\hline
\end{tabular}


Inspected Wells

\begin{tabular}{|c|c|c|c|}
\hline $\begin{array}{c}\text { Well } \\
\text { Number }\end{array}$ & Location & $\begin{array}{l}\text { Reference } \\
\text { Tag Depth }\end{array}$ & $\begin{array}{c}\text { Well } \\
\text { Status/Function }\end{array}$ \\
\hline GW-101 & S-3 Site & 19.18 & UCOR-Active/SMPLML \\
\hline GW-105 & S-3 Site & 19.40 & Active $M$ L \\
\hline GW-106 & S-3 Site & 74.10 & Active \\
\hline GW-107 & S-3 Site & 16.30 & Inactive \\
\hline GW-108 & S-3 Site & 58.30 & UCOR-Active $M$ L \\
\hline GW-109 & S-3 Site & 125.45 & UCOR-Active/SMPL \\
\hline GW-115 & S-3 Site & 54.49 & Active $M$ L \\
\hline GW-117 & Bear Creek Burial Grounds WMA & 533.06 & Inactive \\
\hline GW-118 & Bear Creek Burial Grounds WMA & 578.02 & Inactive \\
\hline GW-119 & Bear Creek Burial Grounds WMA & 512.99 & Inactive \\
\hline GW-120 & Oil Landfarm WMA & 184.19 & Inactive \\
\hline GW-121 & Oil Landfarm WMA & 607.68 & Inactive \\
\hline GW-122 & S-3 Site & 145.28 & Active \\
\hline GW-123 & S-3 Site & 574.79 & Inactive \\
\hline GW-124 & S-3 Site & 153.44 & Inactive \\
\hline GW-125 & S-3 Site & 553.68 & Inactive \\
\hline GW-126 & Bear Creek Burial Grounds WMA & 159.18 & Inactive \\
\hline GW-127 & S-3 Site & 26.52 & UCOR-Active/WL \\
\hline GW-131 & Scarboro Road & $1099.4^{\star \star}$ & Inactive \\
\hline GW-132 & S-3 Site & $762.42^{\star \star *}$ & Inactive \\
\hline GW-133 & S-3 Site & $602.26^{\star \star}$ & Inactive \\
\hline GW-134 & S-3 Site & $845.13^{\star \star}$ & Active \\
\hline GW-135 & S-3 Site & $1277.38^{\text {* }}$ & Inactive \\
\hline GW-141 & Industrial Landfill IV & 158.81 & Active $M$ L \\
\hline GW-142 & Kerr Hollow Quarry & 298.20 & Active $M L$ \\
\hline GW-143 & Kerr Hollow Quarry & 252.7 & UCOR-Active \\
\hline GW-144 & Kerr Hollow Quarry & 194.34 & UCOR-Active $\mathrm{ML}$ \\
\hline GW-145 & Kerr Hollow Quarry & 113.49 & UCOR-Active $\mathrm{WL}$ \\
\hline GW-146 & Kerr Hollow Quarry & 217.01 & Inactive \\
\hline GW-147 & Kerr Hollow Quarry & 72.82 & Inactive \\
\hline GW-148 & New Hope Pond & 13.93 & Active $M L$ \\
\hline GW-149 & New Hope Pond & 50.35 & UCOR-Active \\
\hline GW-150 & New Hope Pond & 14.75 & Inactive \\
\hline GW-151 & New Hope Pond & 99.63 & UCOR-Active $/ \mathrm{ML}$ \\
\hline GW-152 & New Hope Pond & 20.76 & UCOR-Active $\mathrm{WL}$ \\
\hline GW-153 & New Hope Pond & 60.84 & UCOR-Active \\
\hline GW-154 & New Hope Pond & $13.55^{\star}$ & UCOR-Active $M$ ML \\
\hline GW-156 & Chestnut Ridge Sediment Disposal Basin & 157.65 & UCOR-Active $M L$ \\
\hline GW-158 & Chestnut Ridge Sediment Disposal Basin & 442.60 & Inactive \\
\hline GW-159 & Chestnut Ridge Sediment Disposal Basin & 155.87 & UCOR-Active $M$ L \\
\hline GW-160 & Chestnut Ridge Borrow Area Waste Pile & 230.52 & Active $M$ L \\
\hline GW-161 & Chestnut Ridge Borrow Area Waste Pile & 402.88 & UCOR-Active \\
\hline GW-162 & Bear Creek Burial Grounds WMA & 128.50 & Inactive \\
\hline GW-163 & Bear Creek Burial Grounds WMA & 27.13 & Inactive \\
\hline GW-164 & Bear Creek Burial Grounds WMA & 406.49 & Inactive \\
\hline GW-165 & Chestnut Ridge/Deer Trap \#10 & 309.37 & Inactive \\
\hline GW-166 & Chestnut Ridge/Deer Trap \#10 & 381.40 & Inactive \\
\hline GW-167 & Scarboro Road & 32.81 & Active $M L$ \\
\hline
\end{tabular}


Inspected Wells

\begin{tabular}{|c|c|c|c|}
\hline $\begin{array}{c}\text { Well } \\
\text { Number }\end{array}$ & Location & $\begin{array}{l}\text { Reference } \\
\text { Tag Depth }\end{array}$ & $\begin{array}{c}\text { Well } \\
\text { Status/Function }\end{array}$ \\
\hline GW-168 & Scarboro Road & 138.13 & UCOR-Active \\
\hline GW-169 & Union Valley - Exit Pathway & 36.23 & UCOR-Active ML \\
\hline GW-170 & Union Valley - Exit Pathway & 156.16 & UCOR-Active \\
\hline GW-171 & Union Valley - Exit Pathway & 32.64 & UCOR-Active \\
\hline GW-172 & Union Valley - Exit Pathway & 137.50 & UCOR-Active \\
\hline GW-173 & Chestnut Ridge Security Pits & 167.34 & Active/ML \\
\hline GW-174 & Chestnut Ridge Security Pits & 151.94 & Active $M$ L \\
\hline GW-175 & Chestnut Ridge Security Pits & 169.49 & UCOR-Active $M L$ \\
\hline GW-176 & Chestnut Ridge Security Pits & 147,33 & Active $M L$ \\
\hline GW-177 & Chestnut Ridge Security Pits & 150.69 & UCOR-Active $M L$ \\
\hline GW-178 & Chestnut Ridge Security Pits & 134.68 & Active $M L$ \\
\hline GW-179 & Chestnut Ridge Security Pits & 122.50 & Active $M L$ \\
\hline GW-180 & Chestnut Ridge Security Pits & 146.08 & ActiveML \\
\hline GW-181 & Chestnut Ridge Security Pits & 169.45 & Inactive \\
\hline GW-183 & Y-12 Fuel Station & 33.30 & Inactive \\
\hline GW-184 & Rogers Quarry & 131.41 & Active $M$ L \\
\hline GW-185 & Rogers Quarry & 470.88 & Inactive \\
\hline GW-186 & Rogers Quarry & 172.02 & Active $M$ L \\
\hline GW-187 & Rogers Quarry & 163.67 & Inactive \\
\hline GW-188 & Rogers Quarry & 73.15 & Active $M$ L \\
\hline GW-189 & Rogers Quarry & 206.56 & Inactive \\
\hline GW-190 & Y-12 Plant Site & 29.84 & Active \\
\hline GW-191 & Beta-4 Security Pits & 65.09 & Inactive \\
\hline GW-192 & Beta-4 Security Pits & 21.58 & Active $M$ L \\
\hline GW-193 & Y-12 Plant Site & 21.17 & UCOR-Active $M L$ \\
\hline GW-194 & Beta-4 Security Pits & 15.88 & Inactive \\
\hline GW-195 & Beta-4 Security Pits & 24.92 & Active $M$ L \\
\hline GW-196 & Beta-4 Security Pits & 28.67 & Inactive \\
\hline GW-197 & Beta-4 Security Pits & 19.67 & Inactive \\
\hline GW-198 & Ravine Disposal Site & 29.57 & Inactive \\
\hline GW-199 & Y-12 Grid Well I1 & 25.92 & Active $M$ L \\
\hline GW-200 & Ravine Disposal Site & 59.96 & Active/ML \\
\hline GW-202 & Ravine Disposal Site & 22.59 & Active/ML \\
\hline GW-203 & UNC Site & 157.61 & UCOR-Active/ML \\
\hline GW-204 & Y-12 Plant Site & 20.23 & Active $M$ L \\
\hline GW-205 & UNC Site & 165.13 & UCOR-Active $M L$ \\
\hline GW-206 & Exit Pathway Scarboro Road/Pine Ridge & 17.12 & Inactive \\
\hline GW-207 & Exit Pathway Scarboro Road/Pine Ridge & 114.73 & Inactive \\
\hline GW-208 & Exit Pathway Scarboro Road/Pine Ridge & 416.62 & Inactive \\
\hline GW-217 & Industrial Landfill IV & 179.13 & UCOR-ActiveML \\
\hline GW-218 & Uranium Oxide Vault & 30.64 & Inactive \\
\hline GW-219 & Uranium Oxide Vault & 15.59 & Active $M L$ \\
\hline GW-220 & New Hope Pond & 49.00 & Active \\
\hline GW-221 & UNC Site & 159.34 & UCOR-Active $M L$ \\
\hline GW-222 & New Hope Pond & 28.55 & Active \\
\hline GW-223 & New Hope Pond & 93.57 & UCOR-Active \\
\hline GW-224 & Rogers Quarry & 126.99 & Inactive \\
\hline GW-225 & Oil Landfarm WMA & 203.30 & Active \\
\hline
\end{tabular}


Inspected Wells

\begin{tabular}{|c|c|c|c|}
\hline $\begin{array}{c}\text { Well } \\
\text { Number }\end{array}$ & Location & $\begin{array}{l}\text { Reference } \\
\text { Tag Depth }\end{array}$ & $\begin{array}{c}\text { Well } \\
\text { Status/Function }\end{array}$ \\
\hline GW-226 & Oil Landfarm WMA & 58.47 & Active ML \\
\hline GW-227 & Oil Landfarm WMA & 42.64 & Active $M$ L \\
\hline GW-228 & Oil Landfarm WMA & 93.45 & Inactive \\
\hline GW-229 & Oil Landfarm WMA & 51.45 & Active $M$ L \\
\hline GW-230 & Union Valley - Exit Pathway & 409.48 & UCOR-Active \\
\hline GW-231 & Kerr Hollow Quarry & 37.70 & UCOR-Active $M$ LL \\
\hline GW-232 & Union Valley - Exit Pathway & 409.48 & Inactive \\
\hline GW-236 & S-3 Site & 21.14 & Active/ML \\
\hline GW-237 & Bear Creek Burial Grounds WMA & 17.26 & Inactive \\
\hline GW-239 & Scarboro Road & 436.17 & Inactive \\
\hline GW-240 & New Hope Pond & 32.55 & Active \\
\hline GW-241 & Chestnut Ridge Sediment Disposal Basin & 98.23 & Active $M L$ \\
\hline GW-242 & Bear Creek Burial Grounds WMA & 20.18 & Active/ML \\
\hline GW-243 & S-3 Site & 76.30 & UCOR-Active \\
\hline GW-244 & S-3 Site & 77.30 & UCOR-Active \\
\hline GW-245 & S-3 Site & 73.87 & UCOR-ActiveML \\
\hline GW-246 & S-3 Site & 76.50 & UCOR-Active/SMPL \\
\hline GW-247 & S-3 Site & 76.50 & UCOR-Active \\
\hline GW-248 & Bear Creek Burial Grounds WMA & 65.21 & Inactive \\
\hline GW-249 & Bear Creek Burial Grounds WMA & 37.85 & Active $M$ L \\
\hline GW-250 & Bear Creek Burial Grounds WMA & 64.83 & Inactive \\
\hline GW-251 & S-2 Site & 50.04 & Active $M$ L \\
\hline GW-252 & S-2 Site & 51.11 & Inactive \\
\hline GW-253 & S-2 Site & $\overline{51.51}$ & UCOR-Active $M L$ \\
\hline GW-255 & S-2 Site & 84.49 & Active $M$ L \\
\hline GW-257 & Bear Creek Burial Grounds WMA & 36.63 & UCOR-Active/ML \\
\hline GW-258 & Bear Creek Burial Grounds WMA & 52.86 & Inactive \\
\hline GW-259 & Bear Creek Burial Grounds WMA & 35.74 & Active \\
\hline GW-261 & Y-12 Grid Well A1 & 26.82 & Active $M$ L \\
\hline GW-262 & Y-12 Grid Well A1 & 72.19 & Inactive \\
\hline GW-263 & Y-12 Grid Well A2 & 33.96 & Active $M$ L \\
\hline GW-264 & Y-12 Grid Well A2 & 74.25 & Inactive \\
\hline GW-265 & Y-12 Salvage Yard & 25.68 & Active \\
\hline GW-268 & Y-12 Salvage Yard & 36.22 & Inactive \\
\hline GW-269 & Y-12 Salvage Yard & 33.50 & Active \\
\hline GW-270 & Y-12 Salvage Yard & 21.50 & Active \\
\hline GW-271 & Y-12 Salvage Yard & 59.33 & Inactive \\
\hline GW-272 & Y-12 Salvage Yard & 19.16 & Active \\
\hline GW-273 & Y-12 Salvage Yard & 35.00 & Inactive \\
\hline GW-274 & Y-12 Salvage Yard & 36.12 & UCOR-Active/SMPL \\
\hline GW-275 & Y-12 Salvage Yard & 68.47 & UCOR-Active/SMPL \\
\hline GW-276 & S-3 Site & 21.34 & UCOR-ActiveMLL \\
\hline GW-277 & S-3 Site & 80.63 & Inactive \\
\hline GW-281 & Y-12 Fuel Station & 14.85 & UCOR-Active \\
\hline GW-282 & Y-12 Fuel Station & 13.23 & Inactive \\
\hline GW-283 & Y-12 Fuel Station & 21.10 & Inactive \\
\hline GW-284 & Y-12 Fuel Station & 18.04 & Inactive \\
\hline GW-285 & Y-12 Fuel Station & 20.51 & Inactive \\
\hline
\end{tabular}




\section{Inspected Wells}

\begin{tabular}{|c|c|c|c|}
\hline $\begin{array}{c}\text { Well } \\
\text { Number }\end{array}$ & Location & $\begin{array}{l}\text { Reference } \\
\text { Tag Depth }\end{array}$ & $\begin{array}{c}\text { Well } \\
\text { Status/Function }\end{array}$ \\
\hline GW-286 & Bear Creek Burial Grounds WMA & 34.78 & Inactive \\
\hline GW-287 & Bear Creek Burial Grounds WMA & 15.19 & Active $M L$ \\
\hline GW-288 & Bear Creek Burial Grounds WMA & 62.70 & Inactive \\
\hline GW-289 & Bear Creek Burial Grounds WMA & 43.14 & UCOR-Active/SMPLML \\
\hline GW-290 & Bear Creek Burial Grounds WMA & 38.18 & Inactive \\
\hline GW-291 & Bear Creek Burial Grounds WMA & 19.92 & UCOR-Active/ML \\
\hline GW-292 & East Chestnut Ridge Waste Pile & 187.59 & UCOR-ActiveML \\
\hline GW-293 & East Chestnut Ridge Waste Pile & 216.40 & UCOR-Active \\
\hline GW-294 & East Chestnut Ridge Waste Pile & 130.76 & UCOR-Active \\
\hline GW-296 & East Chestnut Ridge Waste Pile & 148.16 & UCOR-Active \\
\hline GW-298 & Chestnut Ridge Borrow Area Waste Pile & 189.36 & UCOR-Active/ML \\
\hline GW-299 & Chestnut Ridge Borrow Area Waste Pile & 169.23 & Active $M L$ \\
\hline GW-300 & Chestnut Ridge Borrow Area Waste Pile & 149.24 & Active $M L$ \\
\hline GW-301 & Chestnut Ridge Borrow Area Waste Pile & 165.23 & UCOR-Active/ML \\
\hline GW-302 & UNC Site & 138.23 & Active $M L$ \\
\hline GW-303 & Chestnut Ridge Sediment Disposal Basin & 322.10 & Active/ML \\
\hline GW-304 & Chestnut Ridge Sediment Disposal Basin & 167.78 & Active/WL \\
\hline GW-305 & Industrial Landfill IV & 181.06 & UCOR-ActiveML \\
\hline GW-306 & Rust Spoil Area & 60.66 & Active \\
\hline GW-307 & Rust Spoil Area & 43.60 & Active/ML \\
\hline GW-308 & Rust Spoil Area & 40.61 & Inactive \\
\hline GW-309 & Rust Spoil Area & 40.06 & Active/ML \\
\hline GW-310 & Rust Spoil Area & 30.47 & Active $M L$ \\
\hline GW-311 & Rust Spoil Area & 43.64 & Inactive \\
\hline GW-312 & Rust Spoil Area & 42.10 & Active \\
\hline GW-313 & Spoil Area I & 121.40 & Inactive \\
\hline GW-314 & Spoil Area I & 118.15 & Inactive \\
\hline GW-315 & Spoil Area I & 105.98 & Active \\
\hline GW-316 & Spoil Area I & 81.64 & Active $M L$ \\
\hline GW-317 & Spoil Area I & 133.33 & Inactive \\
\hline GW-318 & Rogers Quarry & 82.62 & Inactive \\
\hline GW-319 & Rogers Quarry & 26.21 & Inactive \\
\hline GW-322 & Chestnut Ridge Security Pits & 191.99 & Active/WL \\
\hline GW-323 & Spoil Area I & 109.59 & Active $M L$ \\
\hline GW-324 & S-3 Site & 81.80 & Inactive \\
\hline GW-325 & S-3 Site & 19.87 & Active $\mathrm{WL}$ \\
\hline GW-331 & Waste Coolant Processing Facility & 32.60 & Inactive \\
\hline GW-332 & Waste Coolant Processing Facility & 27.07 & Active \\
\hline GW-333 & Waste Coolant Processing Facility & 27.46 & Inactive \\
\hline GW-334 & Waste Coolant Processing Facility & 29.72 & Active/ML \\
\hline GW-335 & Waste Coolant Processing Facility & 17.29 & Active $M$ L \\
\hline GW-336 & Waste Coolant Processing Facility & 23.93 & Inactive \\
\hline GW-337 & Waste Coolant Processing Facility & 25.33 & Active \\
\hline GW-338 & Waste Coolant Processing Facility & 20.20 & Inactive \\
\hline GW-339 & UNC Site & 116.92 & Active $\mathrm{ML}$ \\
\hline GW-342 & Bear Creek Burial Grounds WMA & 72.28 & Inactive \\
\hline GW-343 & Bear Creek Burial Grounds WMA & 198.70 & Inactive \\
\hline GW-344 & Bear Creek Burial Grounds WMA & 317.92 & Inactive \\
\hline
\end{tabular}


Inspected Wells

\begin{tabular}{|c|c|c|c|}
\hline $\begin{array}{c}\text { Well } \\
\text { Number }\end{array}$ & Location & $\begin{array}{l}\text { Reference } \\
\text { Tag Depth }\end{array}$ & $\begin{array}{c}\text { Well } \\
\text { Status/Function }\end{array}$ \\
\hline GW-345 & S-3 Site & 29.16 & Active $M$ L \\
\hline GW-346 & S-3 Site & 68.13 & Inactive \\
\hline GW-347 & S-3 Site & 30.52 & Active $M$ L \\
\hline GW-348 & S-3 Site & 83.33 & Inactive \\
\hline GW-349 & S-2 Site & 27.81 & Active $M$ L \\
\hline GW-350 & S-2 Site & 46.85 & Inactive \\
\hline GW-363 & Oil Landfarm WMA & 77.27 & UCOR-Active \\
\hline GW-364 & Industrial Landfill I & 62.86 & Active/ML \\
\hline GW-365 & Industrial Landfill I & 152.49 & Active \\
\hline GW-366 & Industrial Landfill I & 104.43 & Inactive \\
\hline GW-367 & Industrial Landfill I & 153.48 & Active \\
\hline GW-368 & Industrial Landfill I & 247.46 & Inactive \\
\hline GW-369 & Industrial Landfill I & 150.30 & Inactive \\
\hline GW-370 & Bear Creek Burial Grounds WMA & 35.44 & Active $M$ L \\
\hline GW-371 & Bear Creek Burial Grounds WMA & 127.56 & Inactive \\
\hline GW-372 & Bear Creek Burial Grounds WMA & 54.24 & Active $M$ L \\
\hline GW-373 & Bear Creek Burial Grounds WMA & 159.06 & Inactive \\
\hline GW-374 & Bear Creek Burial Grounds WMA & 152.43 & Inactive \\
\hline GW-375 & Bear Creek Burial Grounds WMA & 163.33 & Inactive \\
\hline GW-376 & Lysimeter Demo & 221.92 & Inactive \\
\hline GW-380 & New Hope Pond & 15.80 & UCOR-Active/ML \\
\hline GW-381 & New Hope Pond & 61.01 & Active \\
\hline GW-382 & New Hope Pond & 173.20 & UCOR-Active \\
\hline GW-383 & New Hope Pond & 26.54 & Active/ML \\
\hline GW-384 & New Hope Pond & 58.21 & UCOR-Active \\
\hline GW-385 & New Hope Pond & 180.32 & Inactive \\
\hline GW-505 & Rust Garage Area & 16.80 & Active \\
\hline GW-508 & Rust Garage Area & 15.11 & Active \\
\hline GW-511 & Chestnut Ridge Security Pits & 156.00 & Active $\mathrm{ML}$ \\
\hline GW-512 & Filled Coal Ash Pond & 64.28 & Active $M$ L \\
\hline GW-513 & Filled Coal Ash Pond & 127.53 & Inactive \\
\hline GW-514 & Filled Coal Ash Pond & 197.13 & UCOR-Active/SMPL \\
\hline GW-520 & Industrial Landfill I & 82.76 & Inactive \\
\hline GW-521 & Industrial Landfill IV & 136.70 & UCOR-Active/ML \\
\hline GW-522 & Industrial Landfill IV & 197.10 & UCOR-Active $M L$ \\
\hline GW-526 & S-3 Site & 123.80 & Active \\
\hline GW-531 & Lysimeter Demo & 41.28 & ActiveML \\
\hline GW-532 & Lysimeter Demo & 31.71 & Inactive \\
\hline GW-533 & Lysimeter Demo & 32.70 & Inactive \\
\hline GW-534 & Lysimeter Demo & 60.20 & Inactive \\
\hline GW-535 & Lysimeter Demo & 27.36 & Inactive \\
\hline GW-537 & Oil Landfarm WMA & 27.35 & Active $M L$ \\
\hline GW-538 & Lysimeter Demo & 45.33 & Inactive \\
\hline GW-539 & Industrial Landfill II & 158.76 & Active $M L$ \\
\hline GW-540 & Industrial Landfill II & 173.83 & UCOR-Active \\
\hline GW-541 & Construction/Demolition Landfill VI & 106.10 & Active/ML \\
\hline GW-542 & Construction/Demolition Landfill VI & 79.09 & Active $M L$ \\
\hline GW-543 & Construction/Demolition Landfill VI & 96.24 & Active $M$ L \\
\hline
\end{tabular}




\section{Inspected Wells}

\begin{tabular}{|c|c|c|c|}
\hline $\begin{array}{c}\text { Well } \\
\text { Number }\end{array}$ & Location & $\begin{array}{l}\text { Reference } \\
\text { Tag Depth }\end{array}$ & $\begin{array}{c}\text { Well } \\
\text { Status/Function }\end{array}$ \\
\hline GW-544 & Construction/Demolition Landfill VI & 111.80 & ActiveML \\
\hline GW-546 & Construction/Demolition Landfill VI & 86.96 & Active $M L$ \\
\hline GW-557 & Industrial Landfill V & 136.07 & UCOR-Active $/ \mathrm{ML}$ \\
\hline GW-558 & South Side Chestnut Ridge & 77.60 & Active $\mathrm{NL}$ \\
\hline GW-559 & South Side Chestnut Ridge & 170.23 & Active $M L$ \\
\hline GW-560 & Construction/Demolition Landfill VII & 82.90 & UCOR-Active $M L$ \\
\hline GW-562 & Construction/Demolition Landfill VII & 61.24 & UCOR-Active $/ \mathrm{ML}$ \\
\hline GW-563 & South Side Chestnut Ridge & 97.63 & Inactive \\
\hline GW-564 & Construction/Demolition Landfill VII & 78.74 & UCOR-Active/ML \\
\hline GW-567 & South Side Chestnut Ridge & 81.89 & Inactive \\
\hline GW-569 & South Side Chestnut Ridge & 113.14 & Inactive \\
\hline GW-576 & South Side Chestnut Ridge & 70.10 & Inactive \\
\hline GW-601 & Oil Landfarm WMA & 358.61 & Active \\
\hline GW- 602 & Oil Landfarm WMA & 211.27 & Inactive \\
\hline GW-603 & New Hope Pond & 76.78 & ActiveML \\
\hline GW-604 & New Hope Pond & 114.28 & Inactive \\
\hline GW-605 & Exit Pathway - Traverse I & 42.00 & UCOR-Active $/ \mathrm{ML}$ \\
\hline GW-606 & Exit Pathway - Traverse I & 174.36 & UCOR/Active/ML \\
\hline GW-608 & Chestnut Ridge Security Pits & 219.80 & UCOR-Active/SMPLML \\
\hline GW-609 & Chestnut Ridge Security Pits & 268.80 & UCOR-Active/SMPLML \\
\hline GW-610 & Chestnut Ridge Security Pits & 120.21 & Active $M L$ \\
\hline GW-611 & Chestnut Ridge Security Pits & 120.26 & Active $M L$ \\
\hline GW-612 & Chestnut Ridge Security Pits & 256.28 & Active/WL \\
\hline GW-613 & S-3 Site & 45.08 & Active $\mathrm{ML}$ \\
\hline GW-614 & S-3 Site & 93.07 & Inactive \\
\hline GW-615 & S-3 Site & 246.84 & UCOR-Active/SMPL \\
\hline GW-616 & S-3 Site & 270.59 & Active \\
\hline GW-617 & Exit Pathway - Traverse E & 20.69 & Active/WL \\
\hline GW-618 & Exit Pathway - Traverse E & 38.30 & Active \\
\hline GW-619 & Fire Training Facility & 43.63 & Active/ML \\
\hline GW-620 & Fire Training Facility & 77.91 & Active \\
\hline GW-621 & Exit Pathway - Traverse B & 42.52 & Active/WL \\
\hline GW-622 & Bear Creek Burial Grounds WMA & 22.05 & Active/WL \\
\hline GW-623 & Bear Creek Burial Grounds WMA & 277.93 & Active \\
\hline GW-624 & Bear Creek Burial Grounds WMA & 30.60 & Active $M L$ \\
\hline GW- 625 & Bear Creek Burial Grounds WMA & 284.83 & Inactive \\
\hline GW-626 & Bear Creek Burial Grounds WMA & 80.92 & Active $M L$ \\
\hline GW-627 & Bear Creek Burial Grounds WMA & 270.96 & Active \\
\hline GW-628 & Bear Creek Burial Grounds WMA & 290.70 & Inactive \\
\hline GW-629 & Bear Creek Burial Grounds WMA & 314.59 & Active \\
\hline GW- 630 & Lysimeter Demo & 30.92 & Active/WL \\
\hline GW-631 & Rust Garage Area & 15.36 & Inactive \\
\hline GW-632 & Rust Garage Area & 14.20 & Inactive \\
\hline GW-633 & Rust Garage Area & 15.75 & Active \\
\hline GW-634 & Rust Garage Area & 14.94 & Inactive \\
\hline GW-636 & Oil Landfarm WMA & 120.63 & Inactive \\
\hline GW- 637 & Oil Landfarm WMA & 30.87 & Inactive \\
\hline GW-638 & Oil Landfarm WMA & 15.48 & Active $M L$ \\
\hline
\end{tabular}


Inspected Wells

\begin{tabular}{|c|c|c|c|}
\hline $\begin{array}{c}\text { Well } \\
\text { Number }\end{array}$ & Location & $\begin{array}{l}\text { Reference } \\
\text { Tag Depth }\end{array}$ & $\begin{array}{c}\text { Well } \\
\text { Status/Function }\end{array}$ \\
\hline GW- 639 & Bear Creek Burial Grounds WMA & 129.64 & UCOR-Active \\
\hline GW-640 & Bear Creek Burial Grounds WMA & 49.88 & Inactive \\
\hline GW-641 & Bear Creek Burial Grounds WMA & 26.32 & Active $M L$ \\
\hline GW-642 & Bear Creek Burial Grounds WMA & 39.90 & Active $M L$ \\
\hline GW-643 & Bear Creek Burial Grounds WMA & 31.48 & Inactive \\
\hline GW-645 & Oil Landfarm WMA & 83.42 & Active $M$ L \\
\hline GW-646 & Oil Landfarm WMA & 78.04 & Inactive \\
\hline GW-647 & Oil Landfarm WMA & 91.91 & Inactive \\
\hline GW-648 & Rust Spoil Area & 82.47 & Inactive \\
\hline GW-649 & S-3 Site & 23.49 & Inactive \\
\hline GW-651 & Bear Creek Burial Grounds WMA & 54.50 & Inactive \\
\hline GW-652 & Bear Creek Burial Grounds WMA & 33.67 & Active $M L$ \\
\hline GW-653 & Bear Creek Burial Grounds WMA & 41.53 & Active/ML \\
\hline GW-654 & Bear Creek Burial Grounds WMA & 19.14 & Active $M L$ \\
\hline GW-655 & Bear Creek Burial Grounds WMA & 67.26 & Inactive \\
\hline GW-656 & Y-12 Plant Site & 20.60 & Active \\
\hline GW-657 & Y-12 Plant Site & 15.03 & Inactive \\
\hline GW-658 & Y-12 Fuel Station & 2064.00 & UCOR-Active \\
\hline GW-659 & Y-12 Fuel Station & 16.10 & Inactive \\
\hline GW-673 & Filled Coal Ash Pond & 116.39 & Inactive \\
\hline GW-674 & Filled Coal Ash Pond & 16.84 & Active/ML \\
\hline GW-676 & Filled Coal Ash Pond & 20.35 & Active/ML \\
\hline GW-677 & Filled Coal Ash Pond & 160.44 & Active/ML \\
\hline GW-678 & Filled Coal Ash Pond & 133.08 & Active $M$ L \\
\hline GW- 679 & Filled Coal Ash Pond & 134.28 & Active $M$ L \\
\hline GW-680 & Filled Coal Ash Pond & 122.24 & Active ML \\
\hline GW-681 & Filled Coal Ash Pond & 172.28 & Inactive \\
\hline GW-682 & Filled Coal Ash Pond & 161.30 & Inactive \\
\hline GW-683 & Exit Pathway - Traverse A & 199.83 & Active $M$ L \\
\hline GW-684 & Exit Pathway - Traverse $A$ & 132.21 & Active $M$ L \\
\hline GW-685 & Exit Pathway - Traverse A & 141.83 & Inactive \\
\hline GW-686 & Coal Pile Trench & 16.23 & Active/ML \\
\hline GW-690 & Coal Pile Trench & 54.89 & Active \\
\hline GW-691 & Coal Pile Trench & 20.39 & Active/ML \\
\hline GW-692 & Coal Pile Trench & 53.05 & Active \\
\hline GW-693 & Coal Pile Trench & 22.93 & Inactive \\
\hline GW-694 & Exit Pathway - Traverse B & 207.27 & Inactive \\
\hline GW-695 & Exit Pathway - Traverse B & 65.28 & Active $M L$ \\
\hline GW-696 & Y-12 Plant Site & 31.70 & Active $M$ L \\
\hline GW-697 & Y-12 Plant Site & 20.32 & Inactive \\
\hline GW-698 & Building 8110 & 74.88 & Active \\
\hline GW-699 & Y-12 Plant Site & 16.33 & Inactive \\
\hline GW-700 & Building 8110 & 33.19 & Active \\
\hline GW-701 & Y-12 Plant Site & 27.82 & Inactive \\
\hline GW-702 & Y-12 Plant Site & 22.64 & Inactive \\
\hline GW-703 & Exit Pathway - Traverse B & 185.29 & Active \\
\hline GW-704 & Exit Pathway - Traverse B & 258.65 & UCOR-Active \\
\hline GW-705 & Exit Pathway - Traverse B & 312.76 & Inactive \\
\hline
\end{tabular}


Inspected Wells

\begin{tabular}{|c|c|c|c|}
\hline $\begin{array}{c}\text { Well } \\
\text { Number }\end{array}$ & Location & $\begin{array}{l}\text { Reference } \\
\text { Tag Depth }\end{array}$ & $\begin{array}{c}\text { Well } \\
\text { Status/Function }\end{array}$ \\
\hline GW-706 & Exit Pathway - Traverse B & 185.79 & UCOR-Active \\
\hline GW-709 & Industrial Landfill || & 83.52 & UCOR-Active $M L$ \\
\hline GW-710 & Exit Pathway - Traverse W & 750.73 & Inactive \\
\hline GW-711 & Exit Pathway - Traverse W & 668.57 & Inactive \\
\hline GW-712 & Exit Pathway - Traverse W & 460.53 & UCOR-Active \\
\hline GW-713 & Exit Pathway - Traverse W & 318.39 & UCOR-ActiveML \\
\hline GW-714 & Exit Pathway - Traverse W & 146.90 & UCOR-Active \\
\hline GW-715 & Exit Pathway - Traverse W & 45.96 & Active/ML \\
\hline GW-722 & Exit Pathway - Traverse J & $642.68^{\star \star}$ & UCOR-Active/SMPL \\
\hline GW-723 & Exit Pathway - Traverse C & 447.24 & Inactive \\
\hline GW-724 & Exit Pathway - Traverse C & 293.60 & Active \\
\hline GW-725 & Exit Pathway - Traverse C & 145.42 & Active \\
\hline GW-726 & Bear Creek Burial Grounds WMA & $602.62^{\star \star}$ & Active \\
\hline GW-727 & Bear Creek Burial Grounds WMA & $1002.77^{\star \star}$ & Active \\
\hline GW-728 & Bear Creek Burial Grounds WMA & 122.05 & Inactive \\
\hline GW-729 & Bear Creek Burial Grounds WMA & $1363.24^{\star \star}$ & Active \\
\hline GW-730 & Bear Creek Burial Grounds WMA & $1428.25^{\star \star}$ & Active \\
\hline GW-731 & Chestnut Ridge Sediment Disposal Basin & 178.53 & UCOR-Active $M L$ \\
\hline GW-732 & Chestnut Ridge Sediment Disposal Basin & 192.84 & UCOR-Active $M L$ \\
\hline GW-733 & Exit Pathway - Traverse J & 259.93 & UCOR-Active $M L$ \\
\hline GW-734 & Exit Pathway - Traverse J & 60.32 & UCOR-Active $M L$ \\
\hline GW-735 & Exit Pathway - Traverse J & 81.81 & Active $M$ L \\
\hline GW-736 & Exit Pathway - Traverse C & 104.00 & Inactive \\
\hline GW-737 & Exit Pathway - Traverse C & 92.03 & Inactive \\
\hline GW-738 & Exit Pathway - Traverse C & 91.78 & Active \\
\hline GW-739 & Exit Pathway - Traverse C & 322.88 & Inactive \\
\hline GW-740 & Exit Pathway - Traverse C & 192.67 & Active $M L$ \\
\hline GW-742 & Chestnut Ridge Security Pits & 422.03 & Inactive \\
\hline GW-743 & Chestnut Ridge Security Pits & 162.56 & Active $M L$ \\
\hline GW-744 & Y-12 Grid Well K1 & 69.28 & Active \\
\hline GW-745 & Y-12 Grid Well K1 & 35.25 & Inactive \\
\hline GW-746 & Y-12 Grid Well K1 & 17.14 & Active/ML \\
\hline GW-747 & Y-12 Grid Well K2 & 82.33 & Active \\
\hline GW-748 & Y-12 Grid Well K2 & 29.80 & Active/ML \\
\hline GW-750 & Exit Pathway - Traverse J & 75.49 & Active \\
\hline GW-751 & $Y$-12 Grid Well J3 & 63.33 & Inactive \\
\hline GW-752 & Y-12 Grid Well J3 & 18.80 & Active/ML \\
\hline GW-753 & Y-12 Grid Well J2 & 73.76 & Inactive \\
\hline GW-754 & Y-12 Grid Well J2 & 27.19 & Active $M$ L \\
\hline GW-755 & Y-12 Grid Well J1 & 63.17 & Inactive \\
\hline GW-756 & Y-12 Grid Well J1 & 18.95 & Active ML \\
\hline GW-757 & Industrial Landfill || & 168.54 & UCOR-Active/ML \\
\hline GW-758 & Y-12 Grid Well G1 & 52.04 & Inactive \\
\hline GW-759 & Y-12 Grid Well G1 & 32.56 & Active/ML \\
\hline GW-760 & Y-12 Grid Well G2 & 63.30 & Inactive \\
\hline GW-761 & Y-12 Grid Well G2 & 18.51 & Active/ML \\
\hline GW-762 & Y-12 Grid Well J-Primary & 62.04 & Active \\
\hline GW-763 & Y-12 Grid Well J-Primary & 20.41 & Active $M L$ \\
\hline
\end{tabular}

Page 10 of 12 
Inspected Wells

\begin{tabular}{|c|c|c|c|}
\hline $\begin{array}{c}\text { Well } \\
\text { Number }\end{array}$ & Location & $\begin{array}{l}\text { Reference } \\
\text { Tag Depth }\end{array}$ & $\begin{array}{c}\text { Well } \\
\text { Status/Function }\end{array}$ \\
\hline GW-764 & Y-12 Grid Well E1 & 68.14 & Inactive \\
\hline GW-765 & Y-12 Grid Well E1 & 35.05 & Active $M$ L \\
\hline GW-766 & Y-12 Grid Well 12 & 48.38 & Inactive \\
\hline GW-767 & Y-12 Grid Well I2 & 21.44 & Active $M$ L \\
\hline GW-768 & Y-12 Grid Well I1 & 67.63 & Inactive \\
\hline GW-769 & Y-12 Grid Well G3 & 62.73 & Active \\
\hline GW-770 & Y-12 Grid Well G3 & 21.68 & Active $M$ L \\
\hline GW-773 & Y-12 Grid Well H2 & 61.66 & Inactive \\
\hline GW-774 & Y-12 Grid Well H2 & 28.87 & Active $M$ L \\
\hline GW-775 & Y-12 Grid Well H3 & 55.98 & Active \\
\hline GW-776 & Y-12 Grid Well H3 & 21.92 & Active $M L$ \\
\hline GW-777 & Y-12 Grid Well B2 & 61.52 & Active ${ }^{\star \star}$ \\
\hline GW-778 & Y-12 Grid Well B2 & 23.55 & Active $\mathrm{WL}^{\star}{ }^{\star}$ \\
\hline GW-779 & Y-12 Grid Well F2 & 65.35 & Active \\
\hline GW-781 & Y-12 Grid Well E3 & 71.07 & Active \\
\hline GW-782 & Y-12 Grid Well E3 & 38.23 & Active \\
\hline GW-783 & Y-12 Grid Well E3 & 17.98 & Active $M$ L \\
\hline GW-790 & Bear Creek Burial Grounds WMA & $1042.32^{\star \star}$ & Active \\
\hline GW-791 & Y-12 Grid Well D2 & 72.45 & Active \\
\hline GW-792 & Y-12 Grid Well D2 & 31.99 & Active $M$ L \\
\hline GW-794 & Above Grade LL Waste Storage Fac. & 42.43 & Inactive \\
\hline GW-795 & Above Grade LL Waste Storage Fac. & 22.61 & Active/ML \\
\hline GW-796 & Industrial Landfill V & 139.82 & UCOR-Active/ML \\
\hline GW-797 & Industrial Landfill V & 135.71 & UCOR-Active $M L$ \\
\hline GW-798 & Construction/Demolition Landfill VII & 134.00 & UCOR-Active $M L$ \\
\hline GW-799 & Industrial Landfill V & 97.58 & UCOR-Active/ML \\
\hline GW- 800 & Oil Landfarm WMA & 32.86 & Active $M$ L \\
\hline GW-801 & Industrial Landfill V & 190.92 & UCOR-Active $M L$ \\
\hline GW-802 & Y-12 Fuel Station & 25.42 & Active \\
\hline GW-803 & Y-12 Fuel Station & 27.76 & Inactive \\
\hline GW-804 & Y-12 Fuel Station & 27.79 & Inactive \\
\hline GW-811 & Spoil Area I & 67.77 & Inactive \\
\hline GW-812 & Spoil Area I & 48.26 & Inactive \\
\hline GW-813 & SY-200 Yard & 28.05 & Inactive \\
\hline GW-814 & SY-200 Yard & 26.28 & Inactive \\
\hline GW-815 & SY-200 Yard & 23,84 & Inactive \\
\hline GW-816 & Exit Pathway Scarboro Road/Pine Ridge & 17.99 & ActiveML \\
\hline GW-819 & Building $9201-2$ & 16.44 & Inactive \\
\hline GW-820 & Building 9201-2 & 17.18 & Active \\
\hline GW-827 & Construction/Demolition Landfill VI & 137.22 & ActiveNML \\
\hline GW-828 & S-3 Site & 169.36 & Inactive \\
\hline GW-829 & S-3 Site & 118.68 & Active/ML \\
\hline GW-831 & Chestnut Ridge Security Pits & 198.06 & UCOR-Active $\mathrm{ML}$ \\
\hline GW-832 & New Hope Pond & 10.36 & UCOR-Active \\
\hline GW-834 & S-3 Site & 16.60 & Inactive \\
\hline GW-835 & S-3 Site & 19.20 & Active $M$ L \\
\hline GW-836 & S-3 Site & 27.57 & Inactive \\
\hline GW-841 & South Campus Fac, Bethel Valley & 10.30 & UCOR-Active \\
\hline
\end{tabular}


Inspected Wells

\begin{tabular}{|l|l|c|c|}
\hline $\begin{array}{c}\text { Well } \\
\text { Number }\end{array}$ & \multicolumn{1}{|c|}{ Location } & $\begin{array}{c}\text { Reference } \\
\text { Tag Depth }\end{array}$ & $\begin{array}{c}\text { Well } \\
\text { Status/Function }\end{array}$ \\
\hline GW-842 & South Campus Fac., Bethel Valley & 28.00 & UCOR-Active \\
\hline GW-843 & South Campus Fac., Bethel Valley & 69.80 & Inactive \\
\hline GW-844 & South Campus Fac., Bethel Valley & 180.10 & Inactive \\
\hline GW-845 & Y-12 Plant Site & 440.06 & UCOR-Active \\
\hline GW-854 & S-3 Site & 16.52 & Inactive \\
\hline GW-855 & S-3 Site & 20.91 & Inactive \\
\hline GW-880 & S-3 Site & 21.54 & Inactive \\
\hline GW-883 & S-3 Site & 21.96 & Inactive \\
\hline GW-916 & EMWMF & 37.9 (est.) & UCOR-ActiveMLL \\
\hline GW-917 & EMWMF & 53.1 (est.) & UCOR-ActiveML \\
\hline GW-918 & EMWMF & 33.0 (est.) & UCOR-Active/ML \\
\hline GW-920 & EMWMF & 56.4 (est.) & UCOR-Active \\
\hline GW-921 & EMWMF & 51.3 (est.) & UCOR-ActiveMLL \\
\hline GW-922 & EMWMF & 46.9 (est.) & UCOR-ActiveMLL \\
\hline GW-923 & EMWMF & 43.7 (est.) & ActiveML \\
\hline GW-924 & EMWMF & 55.9 (est.) & UCOR-ActiveMLL \\
\hline GW-925 & EMWMF & 150.1 (est.) & UCOR-Active \\
\hline GW-926 & EMWMF & 145.9 (est.) & UCOR-Active \\
\hline GW-927 & EMWMF & 93.2 (est.) & UCOR-Active \\
\hline GW-928 & Y-12 Grid Well C1 & 45.39 & Active \\
\hline GW-929 & Y-12 Grid Well C1 & 30.36 & ActiveML \\
\hline GW-930 & Y-12 Grid Well D1 & 44.52 & Active \\
\hline GW-931 & Y-12 Grid Well D1 & 22.98 & ActiveML \\
\hline GW-934 & New Hope Pond & N/A** & Active \\
\hline GW-954 & Y-12 Plant Site & N/A\# & Active \\
\hline GW-956 & Y-12 Plant Site & N/A\# & Active \\
\hline GW-959 & Big Spring Mercury Treatment Facility & 8.10 & ActiveML \\
\hline GW-960 & Y-12 Grid Well F2 & 27.29 & Active/ML \\
\hline GW-961 & EMWMF & N/A & UCOR-Active \\
\hline GW-964 & EMWMF & N/A & UCOR-Active \\
\hline GW-965 & EMWMF & N/A & UCOR-Active \\
\hline GW-966 & Y-12 Fuel Station & Active/ML \\
\hline
\end{tabular}

Notes:

W.: water level well

SMPL: UCOR well sampled by GWPP

?. unknown

N/A: not applicable/no depth available

*: Westbay well

\#. Bar-cad well

Est: estimated depth - from elevation data

UCOR: monitored and maintained under a UCOR program/project

: slated for P\&A to accommodate UPF construction

(GW-777 and GW-778; last sampled: 2013)

EMWMF: Environmental Management Waste Management Facility 


\section{Distribution:}

U.S. DEPARTMENT OF ENERGY

J. P. Donnelly, DOE-NNSA

B\&W Y-12 Technical Services L.L.C.

V. J. Brumback

C. C. Hill

S. B. Jones

S. E. McNamara

E. R. Schultz

L. O. Vaughan

Y-12 Record Services (Electronic Copy-OSTI)

9114DML-01971865.6551-RC

YDCC-RC

URS/CH2M Oak Ridge (UCOR) L.L.C.

E. A. Brucken

T. S. Bunch

M. E. Cleveland

R. H. Ketelle

L. M. Sims

File - EMEF-DMC

File - Y-12 Project PDCC

ELVADO ENVIRONMENTAL, LLC

T. R. Harrison

J. R. Walker

SCIENCE APPLICATION INTERNATIONAL CORPORATION

T. J. Coffey

W. K. Jago

TENNESSEE DEPARTMENT OF ENVIRONMENT AND CONSERVATION, DOE OVERSIGHT

J. E. Sebastian

UT-BATTELLE L.L.C.

D. B. Watson 